\title{
Responsibility and Limited Liability in Decision Making for Others - An experimental consideration*
}

\author{
Sascha Füllbrunn ${ }^{\dagger} \quad$ Wolfgang J. Luhan ${ }^{\ddagger}$
}

June 25, 2019

\begin{abstract}
Agency in financial markets has been claimed to foster excessive risk taking, ultimately leading to bubble formation. The main driving factor appears to be the skewed bonus system for agents who invest other people's money. The resulting excessive risk taking on behalf of others would imply that such bonus systems crowds out responsible decision making for others in order to serve egoistic self-interest. To test this implication, we conduct laboratory experiments comparing decision making for others with and without such a bonus system. First, we show that, in the absence of bonus systems, decision makers invested significantly less for others than for themselves. Second, we show that limited liable decision makers - participating only in gains but not in losses - invested substantially more for others than for themselves. Hence, our results suggest that indeed limited liability outweighs responsibility.
\end{abstract}

JEL: C91, D03, D81, G11

Keywords: financial decision making, responsibility, limited liability, decision making for others, risk preferences, experiment

\footnotetext{
*We thank seminar participants at the University of Dallas, Texas A\& M, University of Göttingen, University of Portsmouth, Radboud University, as well as conference participants of ESA meetings in Zurich, Dallas, Berlin, and Florida and of the SEF meeting at Radboud Univerity for valuable comments; in particular, we thank participants of the Decision Making for Others Meeting at Radboud University in 2018. We gratefully acknowledge funding by the Ruhr-University Bochum's Young Researchers Funds.

${ }^{\dagger}$ Radboud University, Institute for Management Research, Department of Economics, Heyendaalseweg 141, 6525 AJ NIJMEGEN, The Netherlands (s.fullbrunn@fm.ru.nl)

${ }^{\ddagger}$ University of Portsmouth, Faculty of Business and Law, Richmond Building, Portland Street, Portsmouth PO1 3DE, United Kingdom, (wolfgang.luhan@port.ac.uk)
} 


\section{Introduction}

Economic research on risk attitudes has traditionally focused on individual decision making without much consideration for potential social influences (see e.g., Dohmen et al., 2011, Eckel and Grossman, 2008b; Harbaugh et al., 2010; Holt and Laury, 2002). As real world decisions are embedded in a social context however, a decision maker is hardly ever the only person affected by the consequences of his actions. In fact, many risky decisions are specifically taken on behalf of a third party, e.g. the decision maker's family or business partners. On a larger scale, a CEO's decision might affect the company or even industry, and political decisions affect a country's future. On financial markets, investors usually put an investment adviser or a money manager in charge of their risky investments. It has been a long standing claim - especially since the last financial crisis - that this practice of delegated portfolio investment, with its skewed bonus systems, leads to excessive risk-taking and ultimately to bubble formation (e.g., Allen and Gorton, 1993). Taking excessive risks with the clients' money is largely attributed to the limited liability payment schemes prevalent in these markets (Allen and Gorton, 1993 Allen and Gale, 2000, Cheung and Coleman, 2014, Kleinlercher et al., 2014). However, the question remains whether such payment schemes alter the money managers' behaviour towards excessive risk taking or whether taking investment decisions on behalf of others -independent of the payment scheme- already increases risk taking.

To answer this question, we study investment decisions for others in a laboratory experiment in conditions with and without limited liability. First, we try to establish whether agency without or with perfectly aligned monetary incentive schemes increases risk taking for others. Second, we introduce limited liability with the propensity to "privatize profits and socialize losses" to see whether this affects risk taking for others. We are the first to consider such a decision environment in the laboratory.

The terms "risky shift" and "cautious shift" introduced by Stoner (1961) describe situations in which the initial individual level of risk preference is altered due to exogenous impacts. Without any prior assumptions, taking responsibility for others could result in a shift in either direction.

In the psychological literature, a prominent explanation for a risky shift is "psychological self-other distance"(e.g., Beisswanger et al., 2003, Cvetkovich, 1972, Stone and Allgaier, 2008 Trope and Liberman, 2010, Wray and Stone, 2005), in which the assessment of a potential loss in a risky situation is decreasing in the distance of the affected party to the decision maker. This finding translates directly to the results from economic experiments which report a risky 
shift in hypothetical risk taking without monetary consequences (e.g., Harrison, 2006, Holt and Laury, 2002, 2005). Albrecht et al. (2011) find that making inter-temporal decisions for others results in lesser activation of areas of the brain that are thought to be engaged in emotion and reward-related processes, than when taking decisions for oneself. The resulting argument would be that decisions made on behalf of a third party are equivalent to situations without any real outcome.

In contrast, Charness and Jackson (2009) propose "responsibility alleviation" as an explanation for a cautious shift. Taking responsibility for a third party's welfare induces pro-social behavior which results in conservative risk taking (Charness, 2000, Charness and Jackson, 2009). Several studies report a cautious shift. Physicians, for example, have been found to prefer treatments with higher mortality rates for themselves than what they recommend to their patients (Garcia-Retamero and Galesic, 2012; Ubel et al., 2011). Managers also try to avoid responsibility for decisions with even a minimal probability of hazardous outcomes (Swalm, 1966, Viscusi et al. 1987). Using controlled laboratory experiments, we aim to ultimately determine whether agency in risky financial decisions leads to increased risk taking and what role limited liability plays in this observation.

In our experiment, a decision maker (henceforth "money manager") took investment decisions for himself and for six other subjects (henceforth "clients") using the investment environment from Gneezy and Potters (1997). First, we tested whether the money manager invests more or less - took more or less risk-for himself than for his clients. In the individual decision making treatment 'IND', the money manager invested for himself only. Further, we needed a treatment in which the money manager invests for his clients only - without any own payoff consequences - denoted as 'OTH'. Finally, we considered a treatment with perfectly aligned payoffs - denoted as treatment 'ALL' - in which the money manager invests the same amount for himself AND for his clients; here, IND and OTH were combined in one decision. With this treatment, we can see whether the money manager invests in line with his egoistic preferences - invests the same amount in IND and in ALL—or whether he steps back to invest in line with his social preferences - invests the same in OTH and ALL. Therefore, we administered a within-subjects design to enable the analysis of individual heterogeneity controlling for order effects. Our study is the first to systematically compare these theoretically very different situations. Second, we implemented limited liability by replacing OTH with a new treatment 'LIM'. Here, the money manager earns a fixed percentage from each client's profit, while an investment failure has no monetary consequence for the money manager. In general, such an option-like payment scheme increases risk taking already in individual decision making. The 
question is, however, whether the money manager takes excessive risks with the clients' money to increase his own payoff, suggesting rather anti-social behaviour. Here, we compare LIM to OTH in a between-subject design.

Our aggregate results indicate investment behavior to be in line with responsibility alleviation, as we observed a clear cautious shift. The money managers invested significantly less when clients bore the consequences $(\mathrm{OTH})$, even when the money manager's payoff was perfectly aligned (ALL). Limited liability, however, changes the picture drastically; money managers show a significant risky shift and invest significantly more in LIM than in OTH. Limited liability clearly crowded out the effects of responsibility.

\section{$2 \quad$ Related Literature}

In recent years a growing body of literature has studied risky decisions for others using economic experiments - finding mixed results. Some studies find evidence for a risky shift using first price sealed bid auctions and multiple price lists (Chakravarty et al., 2011) or investment decisions (Polman, 2012, Pollmann et al., 2014, Sutter, 2009). In contrast, plenty of studies find evidence for a cautious shift using lottery choices (Reynolds et al., 2009, Bolton and Ockenfels, 2010), investment decisions (Eriksen and Kvaløy, 2010), or strategic risk taking in stag-hunt games (Charness and Jackson, 2009). Pahlke et al. (2015) find both, a risky shift in the loss domain and a cautious shift in the gain domain using a battery of lotteries. Finally, using a multiple price list Andersson et al. (2016) find little evidence for a significant shift in either direction. All studies listed above consider 'risk taking for others'. They focus on the difference between making a decision for oneself and making the same decision for an anonymous stranger. However, there are important differences in the decision maker's payoff when making decisions for others. Either the decision maker decides for the others only and earns a lump sum payment independent of the client's earnings (OTH), or the decision maker makes the same decision for himself and the others with equal payoff consequences (ALL). The previous studies on decision making for others have each exclusively considered either OTH or ALL 17 While standard models of rational behavior predict similar investments in IND and ALL, based on the decision maker's utility function without other-regarding preferences, there is no standard-theoretical prediction in OTH (Eriksen and Kvaløy, 2010). We conduct a systematic study of the impact of these two types of decision making for others, by implementing both treatments using a within-subjects design.

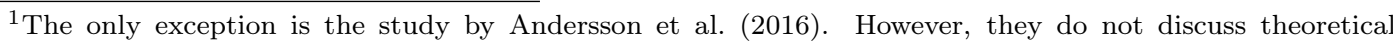
differences nor do they compare OTH and ALL in their analysis.
} 
Convex incentive structures in financial institutions seem to foster excessive risk taking in financial markets, which is supposed to be one of the causes for market bubbles (e.g., Bebchuk and Spamann, 2009, Dewatripont et al., 2010, French et al., 2010, Gennaioli et al., 2012). Rajan (2006) even argues that one of the main origins of instability in highly developed financial markets are widely used convex incentives structures. In many cases, the managers' incentives are barely aligned with the investors' interests. The agency problem of misaligned incentives of money managers and their clients and its effects on markets is theoretically considered by Allen and Gorton (1993); money managers do not share the losses but earn a proportion of the profits. Such a convex incentive structure induces the money managers to trade at prices above fundamental value, causing a price bubble. Holmen et al. (2014) tested this conjecture experimentally and found convex incentives to inflate prices. However, the experimental literature only s convex incentive structures and the effects on markets. What appears to be missing are the effects on investment decisions when clients are immediately affected, i.e. when a money manager is investing the clients' money facing convex incentive structures. We aim to fill this gap.

\section{Design and Procedures}

In this experiment, subjects made investment decisions in line with Gneezy and Potters (1997) which is an established tool to elicit investment decisions under different conditions. The amount invested provides a good metric for capturing treatment effects and differences in attitudes toward risk taking between individuals; see Charness et al. (2013) for a detailed discussion. We consider four different decision environments: individual decision making ('IND'), decision making for others ('OTH'), decision making for others and for oneself ('ALL'), and decision making under limited liability ('LIM') using a mixture of within- and between-subject comparisons.

\subsection{Experimental Design}

In our individual decision making treatment ('IND', I), each subject was endowed with nine euro and was asked to decide on the amount to invest in a risky asset 2 With a probability of $2 / 3$ the amount invested was lost and with a probability of $1 / 3$ the investment was returned in addition to a gain of 2.5 times the amount invested. For $X \in\{0,9\}$ being the amount invested, the subject earned either $\pi^{I}=9-X$, in case of a loss, or $\pi^{I}=9+2.5 X$, in case of a win.

In our others treatment ('OTH', O), subjects were randomly organized in groups of seven,

\footnotetext{
${ }^{2}$ Instructions can be found in the appendix section B.4
} 
consisting of six passive members, the clients $(c)$, and one active member, the money manager $(m)$. Each client was endowed with nine euro and the money manager decided on the amount to invest in the risky asset for each of the six clients. The amount invested was identical for all clients. Hence, each client earned either $\pi_{c}^{O}=9-X$, in case of a loss, or $\pi_{c}^{O}=9+2.5 X$, in case of a win. The money manager was unaffected by the outcome of the investment, $\pi_{m}^{O}=0$. Additionally, we ran some extra sessions ('OTH315') with $\pi_{m}^{O}=31.5$ to test whether a high fixed payment - the highest possible payment for the client —affected the money manager's investment decision. In contrast to the literature, we significantly increase responsibility for others as each money managers invested on behalf of six clients instead of only one.

In our aligned treatment (' $A L L ', A)$, we implemented the same group protocol as in $\mathrm{OTH}$, but also endowed the money manager with nine euro. Now, the money manager decided on the amount to invest which was binding for each of the six clients and for himself. Each subject, the clients and the money manager, earned either $\pi_{c}^{A}=\pi_{m}^{A}=9+2.5 X$ in case of a win or $\pi_{c}^{A}=\pi_{m}^{A}=9-X$ in case of a loss.

In our limited liability treatment ('LIM', L), we also implemented the same group protocol as in OTH. In contrast, the money manager earned a fee which equaled five percent from each clients' profit in case of a win. In case of a loss, however, the money manager faced no monetary consequences. Hence, in case of a win the payoff was $X_{m}^{L}=0.05 \times 6 \times 2.5 X$ for the money manager and $X_{c}^{L}=9+(1-0.05) \times 2.5 X$ for each client. In case of a loss, the payoff was $X_{m}^{L}=0$ for the money manager and $X_{c}^{L}=9-X$ for each client. Hence, the money manager participated only in gains but not in losses. However, th fee is quite small; note that risking the entire endowment for all clients (in total 54 euro) earns an expected payoff of just about 2.25 euro for the money manager. To control whether the magnitude of the fee influenced the decision, we ran some extra sessions (treatment 'LIM50') in which the fee equaled 50 percent instead of five percent. Now, the payoff in case of a win was changed to $X_{m}^{L}=0.5 \times 6 \times 2.5 X$ for the money manager and $X_{c}^{L}=9+(1-0.5) \times 2.5 X$ for each client. Hence, the clients' expected earnings for $X$ euro invested was negative: $(1-0.5) \times 2.5 X \times 1 / 3-X \times 2 / 3=-1 / 4 X$. Any amount invested yields an expected loss for the clients but high expected gains for the money manager.

\subsection{Implementation}

The experiment was programmed and conducted using $\mathrm{z}$-Tree (Fischbacher, 2007). Upon arrival subjects were randomly placed at computer terminals separated by blinds. For each treatment, 
instructions were read aloud separately and questions were answered privately. The experiment only started once the instructor was sure that all subjects had comprehended the instructions. Once the experiment started, each money manager was endowed with an on-screen calculator which calculates potential payoffs for the money manager himself and/or the clients for arbitrarily entered investment levels (screenshots can be found in appendix B.5). Eventually, the money manager selected one investment from the generated list and confirmed his choice.

In each session, the subjects made investment decisions in three separate treatments. To exclude hedging effects from repetitions or cross-game effects, only one of the three treatments was payoff relevant (Charness et al., 2016). The subjects were informed that the experiment would consist of three independent parts, without specifying the exact nature of each part upfront. The instructions for each part were distributed only after the previous part was concluded.

In $O T H, A L L$, and $L I M$, each subject made the investment decision in the role of the money manager. At the end of the session, one of the seven subjects was randomly determined to be the active money manager while the remaining six subjects became the passive clients. To avoid accountability effects, we guaranteed anonymity (Pollmann et al., 2014$)$. Neither the money managers knew the identity of the clients nor did the clients know the identity of the money manager.

To avoid psychological anchoring effects, such as gamblers fallacy or hot hand fallacy, subjects did not receive any information on the outcome of their investments. To determine the payoffs, one subject first threw a dice to determine the payoff relevant treatment and then threw a dice for each group to determine the outcome of the investment. The computer finally assigned the roles as money manager and clients in a group. Subjects were payed privately in cash.

We additionally elicited sex, age, field of study, self-reported risk preferences (Dohmen et al. 2011), and a social responsibility indicator (Berkowitz and Lutterman, 1968). The latter two provide information on the general willingness to take risks (likert scale, 1-10) and social responsibility, the tendency to help others without expecting any immediate personal reward (score from eight likert scales 1-7).

All sessions were conducted at the [double-blind, location hidden]. Our participants were mainly bachelor students from all departments of [double-blind, location hidden]. Subjects participated only once in this experiment. Figure 1 provides an overview of the implementation and the comparisons together with the investment means for all treatments.

To answer our first research question, whether money managers take more or less risk for 
Figure 1: Overview of experiments with strategy for comparison

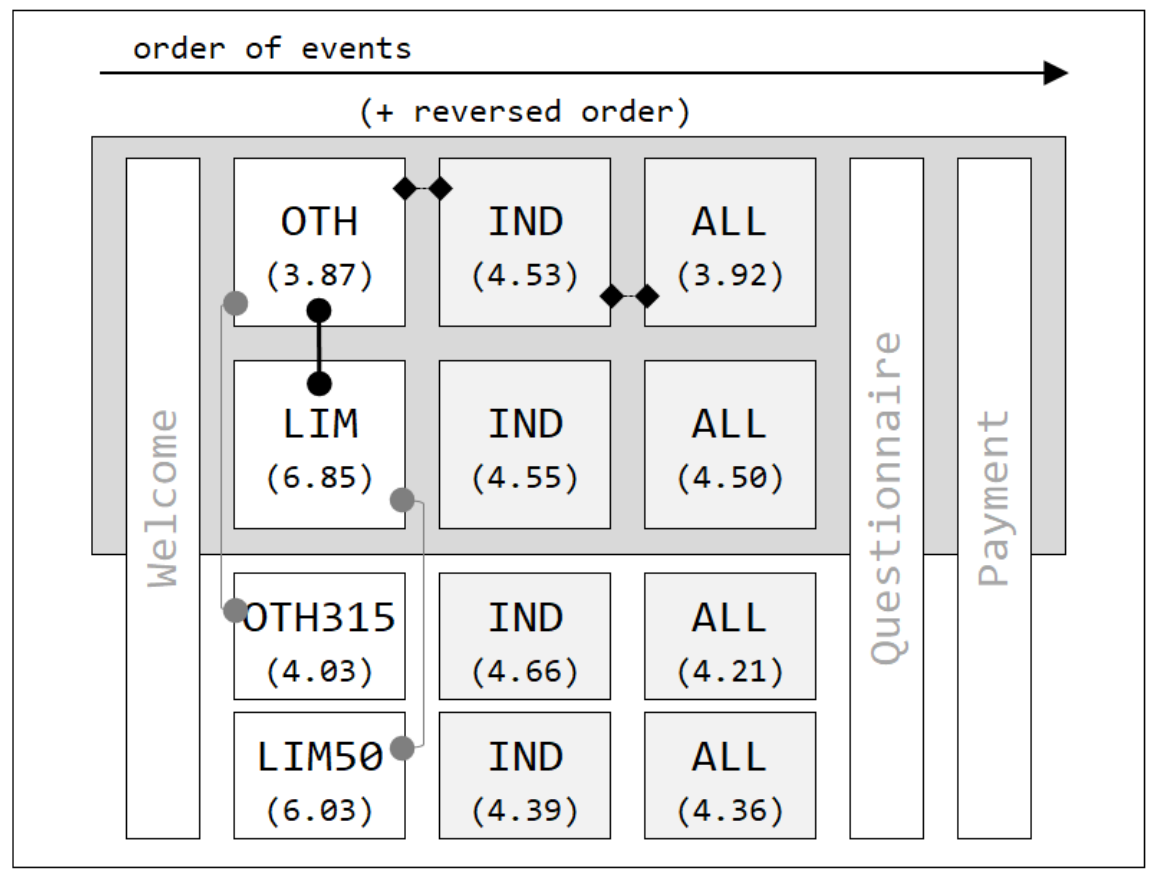

Notes. The figure shows the treatments as conduced in the sessions with ALL as the last treatment; however, we also tested for order effects. Additionally, we provide the investment means. The links with diamonds indicate withinsubject considerations and links with bullets between-subject considerations.

others than for themselves, we ran 15 sessions with a total of 140 participants. We implemented two different setups. In setup one (70 observations), the treatment order was OTH-IND-ALL. In setup two (70 observations), the treatment order was ALL-IND-OTH. Average payments were 15.82 euro (max. 34.5, min. 3, SD 10.10) including a show-up fee of 3 euro. As indicated in figure 1. we make use of a within-subject consideration (links with diamonds). Additionally, we ran three high payoff sessions in the order OTH315-IND-ALL (35 observations). Average payments were 10.95 euro (max. 34.5, min. 3, SD 8.64) including a show-up fee of 3 euro. Here, we aimed to compare OTH315 to OTH. All sessions lasted roughly half an hour.

To answer the question whether limited liability has an impact on decision making for others, we ran five sessions with a total of 105 participants. We implemented two different setups. In setup one (49 observations), the treatment order was LIM-IND-ALL. In setup two (56 observations), the treatment order was ALL-IND-LIM. Average payments were 16.43 euro (max. 34.5, min. 3, SD 10.74) including a show-up fee of 3 euro. To see whether the size of the fee plays an important role, we ran three additional sessions with high fees, 50 percent, in the order LIM50-IND-ALL (21) and ALL-IND-LIM50 (28). Average payments were 16.27 euro (max. 70.5, min. 8, SD 12.75) including a show-up fee of 3 euro. The experiments lasted about half an hour. As indicated in figure 1, we make use of between-subject considerations (links 
with bullets).

\subsection{Predictions}

Our experimental setup focuses on two considerations. The first consideration is about the differences in decision making for others and for oneself using the sessions with the treatments IND, ALL, and OTH (140 observations). Our second focus lies on the implementation of limited liability, comparing mainly the 140 observations in OTH to the 105 observations in LIM.

For the first consideration, we are less interested in individual investment levels; our focus lies on the shift of investments comparing IND and OTH, and IND and ALL respectively. As stated above, the decision in IND will be determined by the subjects' risk preferences (Charness et al. 2013). For the decisions in ALL, economic standard models of perfectly rational and egoistic agents make clear predictions. Without other-regarding preferences the money manager is just investing the same amount as in IND, i.e. $X_{I}=X_{A}$. However, the standard models provide no predictions for $\mathrm{OTH}$ as the payment for the money manager is not aligned to the investment decision. Eriksen and Kvaløy (2010) as well as Andersson et al. (2016) pick up the social distance hypothesis arguing that loss aversion is less pronounced when deciding for others than when deciding for oneself, as these decisions are perceived as less important. Indeed Füllbrunn and Luhan (2017) report experimental evidence for lower levels of loss aversion when decisions are taken for others compared to decisions for oneself. However, our setup by design does not emphasize losses as the payoff on screen is framed only in the gain domain (the total payoff is displayed). Coming back to responsibility alleviation (Charness, 2000; Charness and Jackson 2009), we should find that money managers' behavior will be more conservative when investing for others, i.e., $X_{I}>X_{O}{ }^{3}$ When the money manager believes his clients to have similar risk preferences as he has, he would - in line with the false consensus effect (Ross et al., 1977) -invest the same amount for himself as for the clients, i.e., $X_{I}=X_{O}$.

Another prominent model to explain differences between risky decisions for oneself and for other, the self-others discrepancy effect, describes a bias when predicting others' risk aversion, as this is perceived to be different from the individual's own risk preference. In the context of our design this would state that money managers evaluate their own risk preferences differently than the risk preferences of their clients (Hsee and Weber, 1997; Eckel and Grossman, 2008a) leading to an observed shift. The direction and magnitude of the predicted shift depends on the

\footnotetext{
${ }^{3}$ As the investment in our experiment has a positive expected payoff, it is not immediately clear that low investments are a "responsible" choice. As one reviewer pointed out, it could be seen as responsible to maximize the clients expected payoffs with a maximal investment. Our definition of a shift driven by responsibility, however, follows Charness and Jackson (2009) who clearly predict a decrease in the risks taken on behalf of others.
} 
risk attitudes of the money managers relative to their clients. If money managers believe their clients to be relatively risk averse, they would invest less for their clients than for themselves $\left(X_{I}>X_{O}\right)$, while money managers who believe their clients to be relatively risk seeking, would invest more for their clients than for themselves $\left(X_{I}<X_{O}\right)$.

The investment decision in ALL might induce a conflict of preferences when the egoistic preferences of the money manager and the social preferences for clients clash. On one side of the spectrum, social preferences play no role $\left(X_{A}=X_{I}\right)$ inline with the economic prediction of an egoistic decision maker who strictly follows his own preferences. On the other end of the spectrum, social preferences for the clients would completely crowd out egoistic preferences, i.e., $X_{A}=X_{O}$. When we assume that both preferences play a role in the consideration of the money manager, the investment in ALL is expected to be in-between investments in IND and OTH, i.e., either $X_{I}>X_{A} \geq X_{O}$ (for a cautious shift) or $X_{I}<X_{A} \leq X_{O}$ (for a risky shift). Note that the interaction of social and/or egoistic preferences in risky decision making can only be studied when all three treatments are considered in a within-subjects design.

In LIM, standard economic theory would predict the money manager to invest the full amount. Such behaviour would also be optimal for risk averse clients. Expected returns from investment are positive and higher investments lead to higher expected payoffs, at least when the fee is merely five percent. Hence, neglecting responsibility as in standard economic theory, we predict subjects to invest the entire amount in the LIM treatments. However, there might be a conflict between the monetary incentives that trigger the egoistic preferences and otherregarding preferences - the former predicting high investment while the latter a rather cautious investment. Nonetheless, high investment in LIM can still be judged as acting in line with risk neutral clients. This argument does not hold any longer for a fee of 50 percent though. Here, the clients clearly suffer from excessive risk taking due to their negative expected payoff (e.g., Allen and Gorton, 1993). In contrast to OTH, the decision maker now has an incentive to take risks in order to earn a positive payoff for himself. If responsibility plays the main role, however, we expect similar investment levels in OTH and LIM. When egoistic preferences play the main role, the money managers will not hesitate to risk the entire endowment of the clients.

\section{Results}

We first consider the effect of risk taking for others by testing within-subjects whether differences exist between $X_{I}, X_{A}$, and $X_{O}$. Then, we consider the effect of limited liability by testing between-subjects whether differences exist between $X_{O}$ and $X_{L}$. We also consider a fixed 
payment effect in OTH (vs. OTH315) and an effect of a 50\% fee in LIM (vs LIM50) betweensubjects. The p-values for the all tests conducted were derived from two sided permutation tests.

\subsection{Risk Taking for Others}

To test whether money managers take more or less risk for others, we use each subject's shift in investments as the relevant unit of observation, i.e., $S_{A}=X_{A}-X_{I}$ and $S_{O}=X_{O}-X_{I}$. While negative values indicate a cautious shift, positive values indicate a risky shift. Table 1 provides averages (and standard deviations) for investment levels and shifts for 140 independent observations 4

Table 1: Average Investments in Euro

\begin{tabular}{lccc}
\hline & & \multicolumn{2}{c}{ General Risk } \\
\cline { 3 - 4 } & $n=140$ & $3.19(1.75)$ & $5.42(2.49)$ \\
& $4.53(2.42)$ & $3.04(1.50)$ & $4.41(1.96)$ \\
$X_{I}$ & $3.92(1.91)$ & $3.24(1.96)$ & $4.27(2.40)$ \\
$X_{A}$ & $3.87(2.21)$ & & $\begin{array}{c}\text { above median risk } \\
(n=64)\end{array}$ \\
$X_{O}$ & $-0.60^{* * *}(1.57)$ & $-0.15(0.85)$ & $-1.01^{* * *}(1.86)$ \\
$S_{A}$ & $-0.65^{* * *}(2.39)$ & $0.05(1.65)$ & $-1.15^{* * *}(2.75)$ \\
$S_{O}$ & &
\end{tabular}

Notes. The second column contains averages for all observations. The next two columns categorize subjects in two groups according to elicitation of risk attitudes in line with Dohmen et al. (2011). Subjects in the group below median (above median) stated below (above) median risk attitudes on a scale from 1 - 10. Rows report average investments and average shifts together with the standard deviation in parentheses. The asterisks refer to the p-value from a permutation test testing the Null that $S$ equals zero $(* *=\mathrm{p}<0.05, * * *=\mathrm{p}<0.01)$.

The table shows that investment levels in ALL and in OTH are on average about 13 and 14 percent lower than in IND, respectively. Using a two-sided permutation test, we confirm a significant cautious shift for ALL and for OTH which is on average at $S_{A}=-0.60(p<0.001)$ and at $S_{O}=-0.65(p<0.001)$, respectively ${ }^{5}$ Thus, we state observation 1

Observation 1. Money managers invest significantly less for their clients than for themselves in $A L L$ and in $O T H$.

This result is a clear indication of acting in line with the responsibility alleviation hypothesis. We find a significant cautious shift, not only in OTH but also in ALL, which is in contrast to the prediction of the standard rationality models.

\footnotetext{
${ }^{4}$ As we find no significant order effect in non-parametric tests and regressions, we pool all 140 observations (see appendix B.1 and A

${ }^{5}$ We find no significant relationship between demographics and decision making for others nor was the social responsibility score significant (see appendix table A.5 and A.6.
} 
The self-other discrepancy might be seen as a refinement of trying to act responsibly, as the money manager tries to act according to the investors risk preferences while deviating from his personal preferences. According to this view, the direction of the observed shift depends on the perceived risk preferences of the clients in comparison to the money managers own risk preferences. Therefore, we conjecture that relatively risk averse subjects invest more for others while relatively risk seeking subjects invest less for others. To test this conjecture, we consider the self-reported willingness to take general risks based on Dohmen et al. (2011) which provides a number from 1 (not willing to take risks) to 10 (willing to take high risk). We make use of a median split to compare two groups; the relatively risk averse subjects (reported general risk below 5) and the relatively risk seeking subjects (reported general risk above 5; we neglect 23 observations at the median). Table 1 indicates that in the below-median group the shift not significantly different from zero. In the above-median group, however, the general pattern observed above is quite strong, i.e., we find a significant cautious shift in ALL and in OTH (for both $p<0.001)^{6}$ As the averages in table 1 already suggest, we find a significant effect comparing above-median group and below-median group for each of the five variables $(p<0.025)$. Thus, we state observation 2 .

Observation 2. Investment levels in $O T H$ and $A L L$ do barely differ for rather risk averse money managers, while rather risk seeking money managers show a significant cautious shift.

Observation 2 appears to be in line with the self-other-distance theory. Money managers in the above median risk group tend to assume that they are relatively risk seeking in comparison to the population while at least the averages suggest the opposite for the risk averse money managers. The decisions for their clients reflect a propensity towards the perceived average preference of their clients; finally, the above median risk level money managers are clearly driving the aggregate results. The regression in the appendix (Table A.5 shows a clear picture: the higher the willingness to take general risks, the higher the cautious shift.

These conclusions are only derived from observed behavior under the assumption that money managers did indeed presume the average risk aversion to be higher or lower than their personal risk preferences. To test whether this assumption was correct or a mere artifact, we let the subjects estimate the investment level $X_{I}$ of the other subjects' (unincentivized) which we denote $X_{I b} 7$ Table 2 reports respective measures.

\footnotetext{
${ }^{6}$ Implementing the same analysis by categorizing subjects according to their observed risk preference in the IND treatment $\left(X_{I}\right)$, we get similar results (see appendix B.3.

${ }^{7}$ To elicit beliefs, we included the question "What would you say, how much do others in your group on average invest for themselves?" in the questionnaire. We abstained from using incentivized believe elicitation methods as this would increase the complexity and duration of the experiment with vague additional benefits (see Trautmann and Kuilen, 2015 for a discussion). Unfortunately, we have elicited the beliefs for 91 subjects
} 
Table 2: Average Beliefs about Investments of Clients

\begin{tabular}{lccc}
\hline & & \multicolumn{2}{c}{ General Risk } \\
\cline { 3 - 4 } & $n=91$ & $\begin{array}{c}\text { below-median risk } \\
(n=36)\end{array}$ & $\begin{array}{c}\text { above-median risk } \\
(n=40)\end{array}$ \\
\hline$X_{I b}$ & $4.41(1.62)$ & $3.85(1.14)$ & $4.65(1.95)$ \\
$X_{I b}-X_{I}$ & $0.00(2.22)$ & $0.77^{* * *}(1.32)$ & $-0.90^{* * *}(2.36)$ \\
$X_{I b}-X_{O}$ & $0.58^{* * *}(2.56)$ & $0.92^{* * *}(1.88)$ & $0.05(3.11)$ \\
\hline
\end{tabular}

Notes. The second column contains observations from 91 subjects from which we elicited beliefs. $X_{I b}, X_{I}$, and $X_{O}$ denote the beliefs about the investments of others in IND, own investment in IND, and investment in OTH, respectively. The next two columns categorize subjects in two groups according to elicitation of risk attitudes in line with Dohmen et al. (2011). Subjects in the group below median (above median) stated below (above) median risk attitudes on a scale from $1-10$. The asterisks refer to the p-value from a permutation test testing the Null that $S$ equals zero $(* *=$ $\mathrm{p}<0.05, * * *=\mathrm{p}<0.01)$.

Taking all observations into account, the average difference between beliefs and own investment is not significantly different from zero $(p=0.979)$. This indicates that money managers on average do not believe others to take less or more risk then they take for themselves. Such thinking might lead money managers to take similar risks for others as they would take for themselves in line with behaviour of financial advisers in Canada (Foerster et al., 2017).

On the individual level, however, the investment level in OTH can still deviate significantly from the expectation of the average risk preference. Thus, we again separate between subjects with general risk below and above the median, and find that the above median money managers believe others to invest significantly less than they do $\left(X_{I b}-X_{I}=-0.90, p<0.001\right)$, while the below median money managers believe others to invest significantly more $\left(X_{I b}-X_{I}=0.77\right.$, $p<0.001)$. However, above-median risk takers generally believe others to take more risk than below-median risk takers $(p=0.036)$.

The question remains, whether money managers in OTH invest in line with their beliefs, i.e., does $X_{I b}-X_{O}=0$ hold? Overall, we find money managers to invest significantly less for their clients than what they believe their clients would invest for themselves $\left(X_{I b}-X_{O}=0.58\right.$, $p=0.033)$. In particular, the below-median money managers invest significantly less for their clients than what they believe their clients would invest for themselves $\left(X_{I b}-X_{O}=0.92\right.$, $p<0.001)$. In contrast, the above median money managers tend to invest in line with their beliefs about others $\left(X_{I b}-X_{O}=0.05, p=0.701\right){ }^{8}$ Overall, the results suggest that money managers are relatively conservative in that they invest at most what they believe the clients would invest for themselves. This supports Bolton et al. (2015), who find that decision makers act according to the preferences of their clients.

Finally, we compare investment levels between OTH and ALL, i.e., a situation in which the only.

${ }^{8}$ However, comparing $X_{I b}-X_{O}$ between the two categories we find no significant difference $(p=0.150)$. 
payment of the money manager is perfectly aligned (ALL) and when the payment is not aligned $(\mathrm{OTH})$. Results in table 1 indicate that differences between $X_{A}$ and $X_{O}$ are negligible when considering all subjects $\left(X_{A}-X_{O}=0.05, p=0.766\right)$, but also when considering subjects below median risk attitudes $\left(X_{A}-X_{O}=-0.14, p=0.501\right)$ and above $\left(X_{A}-X_{O}=0.32, p=0.246\right)$. Hence, overall it seems that money managers in ALL put their egoistic preferences on hold to match the preferences of the clients indicated by OTH ${ }^{9}$

One caveat in our design might be the unequal payments of the active money manager and the passive client in OTH. While the clients' expected earnings are positive, the money managers' earnings are zero. When fairness preferences come into play, the money manager might change his behavior to match his preferences for a fair allocation of payments (Fehr and Schmidt, 1999, Bolton and Ockenfels, 2000, Charness and Rabin, 2002, 2005; Fudenberg and Levine, 2012). However, models that incorporate risk preferences and fairness preferences are missing. Nonetheless, we wanted to control whether the money manager's fixed payment in OTH has an influence on decision making for others. Therefore, we compared the investment levels in treatment OTH315 and OTH. We find no significant difference in investments comparing the two treatments (see appendix section B.2 and the regression in appendix table A.5 and A.6) suggesting that the money manager's own unrelated payoff when deciding for his clients in OTH plays a minor role. However, the power is not sufficient to claim that investment levels in OTH315 and OTH come from the same population 10

\subsection{Limited Liability}

Section 4.1 shows that money managers in OTH invested less for others than for themselves. In this section, we compare investment levels and shifts in OTH and in LIM between-subjects. Figure 2 shows average investments (A) for IND (as the benchmark), OTH, and LIM and the histograms (B) of OTH and LIM ${ }^{11}$ Both figures show a clear difference between OTH and LIM, i.e. subjects invest more in LIM than in OTH.

Table 4 reports the descriptives of the investments and shifts together with test statistics for different categories of subjects. Considering the full data set, we find a clear and significant difference between investing in OTH and in LIM. On average, the money managers invested 2.79 euro more in LIM than in OTH, a 77 percent increase. Even though order played a role

\footnotetext{
${ }^{9}$ However, even with $n=140$ we would not be able to detect a small effect size of 0.2 as the power would be only 0.63. Merging the data with observations from OTH315, i.e. having 175 observations, we still find no significant difference but for the same parameters we get a decent power of 0.73 .

${ }^{10}$ For a small effects size of 0.2 , the power for a given number of observations of 70 and 35 respectively (same order sessions) would be 0.28 .

${ }^{11}$ We neglect ALL as the relevant comparison is between OTH and LIM.
} 
Figure 2: Comparing Investments: OTH vs LIM

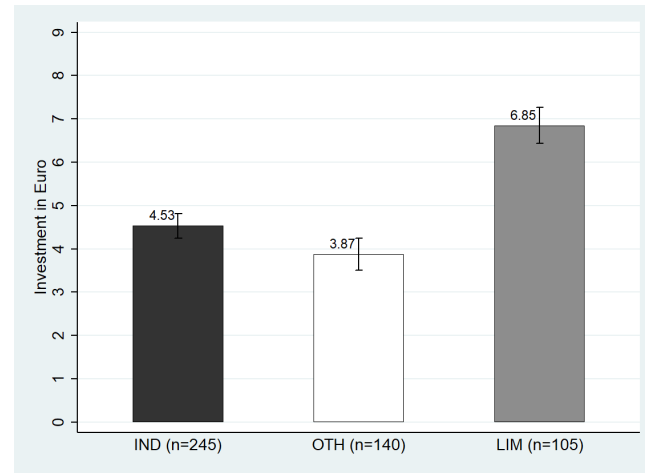

(a) Average investments

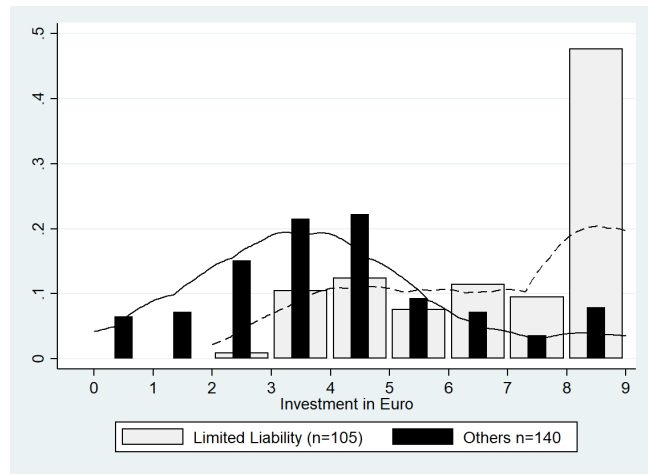

(b) Histogram of investments

Notes. Panel (a) displays average investment levels separated by treatments. The column labelled IND displays the average investment for Experiments 1 and 2 combined. Error bars show the standard error. Panel (b) displays the histogram of investments in OTH and LIM. The respective curves show the kernel densities-the solid line for OTH and the dashed line for LIM.

in the sessions with LIM, i.e., money managers invested about one euro more when LIM was played last than when LIM was played first $(p=0.014)$, investment levels and shifts remain significantly higher in LIM than in OTH in both orders.

Additionally, we conducted a full analysis of session and treatment effects in a panel regression for which the results are reported in table 3 . The dependent variable is the investment level in euro. To compare the treatments in the sessions with OTH, 'OTH-sessions', to the sessions with LIM, 'LIM-sessions' (row one vs. row two in the grey area in figure 1), we introduce LIM session as a dummy for the latter sessions. Further, the dummy $A L L$ equals 1 if ALL is played (and zero otherwise) and the dummy $O T H^{*}$ equals 1 if the decision is made for others (and zero otherwise), which is OTH in the OTH-sessions and LIM in the LIM-sessions. The references was therefore the investment in IND in the OTH-sessions. Model 2 adds subjects characteristics. 
Table 3: Session and treatment effects on investment

\begin{tabular}{|c|c|c|}
\hline independent: investment & (1) & $(2)$ \\
\hline $\mathrm{OTH}^{*}$ & $\begin{array}{c}-0.65^{* * *} \\
(0.20)\end{array}$ & $\begin{array}{c}-0.65^{* * *} \\
(0.20)\end{array}$ \\
\hline ALL & $\begin{array}{c}-0.60^{* * *} \\
(0.13)\end{array}$ & $\begin{array}{c}-0.60^{* * *} \\
(0.13)\end{array}$ \\
\hline LIM sessions & $\begin{array}{l}0.020 \\
(0.29)\end{array}$ & $\begin{array}{l}0.026 \\
(0.25)\end{array}$ \\
\hline ALL $\times$ LIM session & $\begin{array}{c}0.56^{* * *} \\
(0.17)\end{array}$ & $\begin{array}{c}0.56^{* * *} \\
(0.17)\end{array}$ \\
\hline $\mathrm{OTH}^{*} \times$ LIM session & $\begin{array}{c}2.95^{* * *} \\
(0.33)\end{array}$ & $\begin{array}{c}2.95^{* * *} \\
(0.33)\end{array}$ \\
\hline Constant & $\begin{array}{c}4.53^{* * *} \\
(0.20)\end{array}$ & $\begin{array}{c}3.04^{* * *} \\
(0.93)\end{array}$ \\
\hline Observations & 735 & 735 \\
\hline Controls & $\mathrm{NO}$ & YES \\
\hline $\begin{array}{l}\text { Wald test } A L L \times L I M s \\
\text { p-value } \\
\chi^{2}\end{array}$ & $\begin{array}{c}T H^{*} \times L I \\
<0.001 \\
64.67\end{array}$ & $\begin{array}{c}<0.001 \\
64.32\end{array}$ \\
\hline
\end{tabular}

Notes. Random-effects panel regression with robust standard errors, variables explained above. Column 1 contains the estimation results without controlling for individual characteristics, column 2 contains the results from the same estimation controlling for gender, age, self-reported risk preferences (Dohmen et al. 2011), and a social responsibility indicator Berkowitz and Lutterman 1968). Standard errors in parentheses. ${ }^{*}=\mathrm{p}<0.1, * *=\mathrm{p}<0.05, * * *=\mathrm{p}$ $<0.01)$.

Firstly, the LIM session dummy is is not significant and close to zero. Hence, investments in IND are not different comparing LIM- and OTH-sessions. Secondly, the OTH* coefficient is significantly negative, which confirms the cautious shift in OTH, while the interaction coefficient $O T H^{*} \times$ LIM-sessions is significantly positive which confirms the risky shift in LIM. Third, the ALL coefficient is significantly negative, which confirms the cautious shift in ALL. However, this effect is diminished in the LIM-sessions, suggested by the significantly positive interaction coefficient $A L L \times L I M$-sessions. Maybe money managers more generally invest more for others in the LIM-sessions than in the OTH-sessions and the risky shift in LIM is just a consequence. However, the interaction with ALL is significantly lower than the interaction with OTH* $^{*}$ confirmed by a Wald test $(p<0.001)$. This result confirms that even if money managers invest generally more for others in the LIM-sessions than in the OTH sessions, the effect is much stronger in $\mathrm{OTH}^{*}$ than in ALL. These results remain unchanged if we control for individual characteristics, as reported in the second column of table 3 .

The significant increase of investments between OTH and LIM still holds if we compare LIM to OTH separately for below- and above-median general risk group (see table 4), i.e. independent of risk attitudes, investments in LIM exceed investments in OTH. To keep this section concise, we provide respective regressions with shifts and investment levels as dependent 
Table 4: Investment in OTH and LIM

\begin{tabular}{|c|c|c|c|c|c|}
\hline & \multicolumn{2}{|c|}{ No Limited Liability } & \multicolumn{2}{|c|}{ Limited Liability } & \multirow[b]{2}{*}{$H_{0}: X_{O}=X_{L}$} \\
\hline & $X_{O}$ & $S_{O}$ & $X_{L}$ & $S_{L}$ & \\
\hline $\begin{array}{l}\text { All } \\
(n=140 / 105)\end{array}$ & $\begin{array}{c}3.87 \\
(2.22)\end{array}$ & $\begin{array}{c}-0.65^{* * *} \\
(2.3)\end{array}$ & $\begin{array}{c}6.85 \\
(2.15)\end{array}$ & $\begin{array}{c}2.30^{* * *} \\
(2.68)\end{array}$ & $<0.001$ \\
\hline $\begin{array}{l}\text { Below Median risk } \\
(n=53 / 40)\end{array}$ & $\begin{array}{c}3.24 \\
(1.96)\end{array}$ & $\begin{array}{c}0.05 \\
(3.13)\end{array}$ & $\begin{array}{c}6.80 \\
(2.25)\end{array}$ & $\begin{array}{c}3.13^{* * *} \\
(2.84)\end{array}$ & $<0.001$ \\
\hline $\begin{array}{l}\text { Above Median risk } \\
(n=64 / 49)\end{array}$ & $\begin{array}{l}4.27 \\
(2.4)\end{array}$ & $\begin{array}{c}-1.15^{* * *} \\
(2.75)\end{array}$ & $\begin{array}{c}6.85 \\
(2.11)\end{array}$ & $\begin{array}{c}1.46^{* * *} \\
(2.43)\end{array}$ & $<0.001$ \\
\hline $\begin{array}{l}\text { OTH/LIM first } \\
(n=70 / 49)\end{array}$ & $\begin{array}{l}3.95 \\
(1.85)\end{array}$ & $\begin{array}{c}-0.77^{* * *} \\
(2.11)\end{array}$ & $\begin{array}{c}6.30 \\
(2.13)\end{array}$ & $\begin{array}{c}1.52^{* * *} \\
(2.49)\end{array}$ & $<0.001$ \\
\hline $\begin{array}{l}\text { OTH/LIM last } \\
(n=70 / 56)\end{array}$ & $\begin{array}{c}3.84 \\
(2.54)\end{array}$ & $\begin{array}{l}-0.53^{*} \\
(2.67)\end{array}$ & $\begin{array}{l}7.33 \\
(2.98)\end{array}$ & $\begin{array}{c}2.06^{* * *} \\
(2.67)\end{array}$ & $<0.001$ \\
\hline
\end{tabular}

Notes. The table reports averages (SD) of investment levels and shifts in the treatments OTH and LIM for all observations, subjects in the category below and above median risk, and in the orders OTH-IND-ALL/LIM-IND-ALL ('first') and in the orders ALL-IND-OTH/ALL-IND-LIM ('last'). The number of observations are in brackets for OTH/LIM. The last column shows the p-values from a permutation test testing the Null $X_{O}=X_{L}$ in the different categories. The asterisks refer to the p-value from a permutation test testing the Null that the shift equals zero $(*=$ $\mathrm{p}<0.1, * *=\mathrm{p}<0.05, * * *=\mathrm{p}<0.01)$. 
variables and a LIM dummy plus controls as independent variables in the appendix (tables A.5 and A.6); these confirm our results as the LIM dummy is significantly positive. Hence, we state observations 3 and 4

Observation 3. Money managers invest significantly more for their clients than for themselves in LIM.

Observation 4. Money Managers show a significant risky shift independent of personal risk attitudes.

This appears to be an indication of egoistic-, monetary incentives crowding out the previously observed effects of responsibility. However, these higher investment levels for others in LIM could in principle stem from the fact that the money managers believe their clients to prefer higher investments. We have shown in section 4.1 that money managers in OTH acted rather cautiously, investing less than, or at most what they believe their clients would invest themselves. While there is no obvious reason for a change in believes, such a shift would in principle explain increased investments even if money managers still try to act responsibly. We therefore again compare the investments with the elicited beliefs. The average difference between $X_{L}$ and $X_{I b}$ equals 1.57 euro (SD 2.52) which is significantly positive $(p<0.001){ }^{12}$ Recall, in OTH the average difference between $X_{O}$ and $X_{I b}$ was -0.58 (SD 2.36) which is significantly negative $(p=0.035)$. Hence, without limited liability the money manager invests rather cautiously for others, as he invests less than he believes others would invest for themselves. With limited liability, however, such cautious investment behavior has disappeared and investment levels were higher than what the money managers believed their clients would prefer.

We implemented additional sessions to test whether a higher fee with negative expected earnings changes the decisions for others for the money manager. The increase to a fee of 50 percent yields an average investment of 6.03 euro (SD 2.90) which is slightly lower than in LIM with a five percent fee $(6.85, p=0.053){ }^{13}$ However, the shift is still significantly positive $\left(S_{L I M 50}=1.64\right.$ euro, SD $\left.2.72, p<001\right)$ and not significantly different to LIM $(p=0.158)$. Again, investments are significantly higher than in OTH $(p<0.01)$. Hence, the money managers in our setting seem to care less about the expected negative consequences for their clients.

As a side effect, the new LIM50 treatment also allows us to consider ex-ante and ex-post fairness. If the money manager strives for equal expected earnings (ex-ante fairness), he should have invested 3.27 euro to have an expected earning of 8.17 euro for each client and himself If instead the money manager strives for equal earnings (ex-post earnings), he should have

\footnotetext{
${ }^{12}$ Unfortunately, we have only 49 observations for the beliefs in this treatment.

${ }^{13}$ See also appendix table A.5
} 
invested 1.44 euro to earn 10.80 euro for clients and himself in case of success; there was no way for equal earnings in case of a loss. Nevertheless, as shown above, the investment in LIM50 is significantly higher than 3.27 euro and of course than 1.44 euro $(p<0.001)$.

Looking at the clients' expected earnings given the investments, we see that they were highest in LIM (average 9.86 euro, SD 0.27), slightly but significantly lower in OTH (9.65 euro, SD 0.37, $p<0.001$ ), and significantly lower in LIM50 (7.49 euro, SD 0.73, $p<0.001)$. In this particular setting, limited liability with a five percent fee increased the clients' expected earnings. On the one hand, the fee is sufficiently low to keep expected earnings positive, and on the other hand, the convex incentives increased the investment levels. However, limited liability with a 50 percent fee makes the investment opportunity unprofitable for the clients due to negative expected returns.

\section{Discussion}

\section{$5.1 \quad$ Risk Taking for Others}

Our first question was, whether making decisions for others, in the absence of limited liability, would lead to a risky or cautious shift as compared to decisions for oneself. In particular, in contrast to the literature, our decision makers make decisions for a substantial number of clients. This is a necessary first step in establishing whether it is limited liability that leads to increased risk taking on financial markets. Overall, we find clear evidence of a cautious shift in both OTH and ALL, which in our experiment is mainly driven by relatively risk seeking money managers. They believe others to be more risk averse than themselves and act accordingly. Our aggregate results are line with the results from Eriksen and Kvaløy (2010) who use a similar design in a between-subject setting with only one client. However, our results differ from those experiments in the literature who find rather a risky shift. How can we explain those mixed results in the literature? In the following, we discuss some suggestions.

The conclusions from the literature are based on aggregate results only and the heterogeneity of subjects with respect to risk attitudes has barely been considered. Due to our within-subject design we are able to take the relative risk attitudes of the money manager into account. We find that our results are driven by the relatively risk seeking subjects. Therefore, any study with a rather risk averse subject pool would find an aggregate risky shift, of course. Differences to Andersson et al. (2016), for instance, might be due to the fact that their subject pool is taken from the general Danish population which has been found to be more risk averse than 
the common student population (von Gaudecker et al., 2012).

Among others, Eriksen and Kvaløy (2010) report that hypothetical decision making for others - the most extreme social distance - leads to higher risk taking in comparison to a situation with monetary consequences. Thus, experiments with higher social distance, which is the case for internet experiments as opposed to laboratory experiments, might lead to higher risk taking for others. Furthermore, our experimental design allows the potential money managers to put themselves into the shoes of their clients, as the money manager becomes a client with a probability of $6 / 7$. This might lead to a higher empathy for the others leading to a cautious shift (as in the equal opportunity mode treatment in Bolton and Ockenfels, 2006).

Experiments in which the subjects pick lotteries rather than making investments, the results seem to support a risky shift in the loss domain or in the mixed domain, while lotteries in the gain domain support a cautious shift (Pahlke et al. 2015$)$. One reason might be that loss aversion is weaker when making decisions for others (see e.g. Füllbrunn and Luhan (2017)). In our Gneezy and Potters (1997) investment game, however, we cannot control the subjects' reference point, as we have no record of the editing phase (Kahneman and Tversky, 1979). When the endowment is integrated, the decision takes place in the gain domain only $(9+2.5 X$ vs. $9-X)$. When the endowment is segregated, the decision takes place in the mixed domain $(2.5 X$ vs. $-X)$. As we provide integrated outcomes on the decision screen, the subjects might have perceived the task in the gain domain (see screenshot appendix B.5p.

While money managers are assumed to know their own preferences, they are uncertain about their clients' preferences; in particular when estimating the preferences of six clients. This creates an ambiguous situation when deciding for others in contrast to when deciding for oneself. From this point of view, our results are in line with ambiguity aversion, as subjects take less risk in a situation with higher ambiguity (e.g., Trautmann and Van De Kuilen, 2015). This effect might be amplified due to comparative ignorance (Fox and Tversky, 1995$)$ as in a withinsubject design subjects are able to compare decisions for others and for themselves. When money managers observe the decision of their clients in OWN beforehand, we would reduce ambiguity and thus can see whether they behave indeed in line with the client's preferences as our results on following their believes suggest, Bolton et al. (2015) also find that the decision maker follows their client's own choice (for one single client). However, how money managers select the level of investment when they know the preferences of several clients in a group remains a question for future research. So far, subjects in a group had to discuss and agree on one common amount to invest; the results support a risky shift (Sutter, 2009).

Further design elements might be interesting to reconsider. For example, we only consider a 
situation under anonymity; the money manager's identity is not revealed nor is s/he accountable for his/her decision. When accountability comes into play, subjects might behave differently. Pahlke et al. (2012) find that accountability leads to reduced risk aversion in mixed lotteries with one 'client'. We consider a situation in which one subject is randomly chosen to be the money manager, i.e. the decision is implemented with probability $1 / 7$. When the money manager knows for sure that his/her decision is implemented, s/he might be even more cautious. Finally, we use a student subject pool for our experiments. It might be interesting to analyze the same situation using the 'relevant decision maker'; Kirchler et al. (2019), for example, consider financial professionals who make investment decisions for others (in a different setting though).

\section{$5.2 \quad$ Limited liability}

Our second research question asked whether limited liability triggers self-interest. Money managers who participate in gains only do not risk their own money but the money of each of the six clients. A risky shift in comparison to OTH would provide evidence that social preferences of money managers are crowded out by egoistic monetary incentives. To be able to answer this question, we invented a new experimental setting which has not been considered in the literature before; in particular, only a substantial number of clients allows for a 'privatizing gains and socializing losses' environment.

We do indeed find a clear indication for a risky shift once we introduce limited liability. This result is not driven by the beliefs about the clients preferences; as money managers invest significantly more for their clients than what they believed their clients would prefer. The investment levels taken for clients are significantly higher than for oneself. This result is quite robust testing for the size of the bonus (5 percent or 50 percent), risk preferences (below- or above-median risk), and order (LIM/OTH played first or last) 14

The size of the bonus does not appear to play any role for this consideration. We compare limited liability treatments with a five percent and a 50 percent bonus and find no difference in investments. Given that the expected payoffs for their clients were negative with a 50 percent bonus, the money managers' decisions are clearly motivated by their own payoff expectations with social preferences playing only an inferior role. In this treatment, investments could be chosen such that expected earnings for the money manager and the clients were equal, both, in line with ex-ante and ex-post fairness. However, we found that the investment levels under limited liability were significantly higher than any fairness benchmark. We only consider two

\footnotetext{
${ }^{14}$ The result is also robust when separating the subjects by sex. For the interested reader, we have added appendix D.11 considering gender effects.
} 
different bonus conditions. Future research might consider different bonus conditions to carve out whether indeed the size of the bonus has an influence on the money manager, in particular if higher bonuses have negative consequences for the clients.

One argument against our interpretation of the effects of limited liability on investment levels might be that the observations are driven by a few participants who, for whatever reason, take the maximum risk, i.e. invest the entire endowment. Without limited liability only six percent invest the entire endowment; with limited liability 37 percent invest the entire endowment (41 percent in the 50 percent condition). The remaining money managers might behave in a similar with and without limited liability. However, we still find a significant risky shift $(p<0.001)$.

\section{Conclusion}

Coming back to our real-world motivation, we asked the question whether limited liability payment schemes on financial markets lead to money managers taking excessive risks when investing their clients' money (e.g., Allen and Gorton, 1993; Allen and Gale, 2000; Cheung and Coleman, 2014, Kleinlercher et al., 2014). Such a situation involves two possible motivational factors that could increase the willingness to take risks, the mere fact that the decision is taken for somebody else, and limited liability. We decided to study both separately in an incremental design. In the first condition, we aimed to establish whether money managers take higher risks for their six clients in absence of limited liability. In a second condition, we introduced limited liability to test whether behaviour changes in comparison to the first condition. We found that agency in itself leads to a cautious shift, i.e. decision makers took less risk with other people's money. However, if gains are shared, while losses remain with the clients, we observe a risky shift, i.e. decision makers took more risk with other people's money. Our results clearly suggest that decision makers on one hand have social preferences and invest more cautiously for others than for themselves. On the other hand these social preferences are crowded out by egoistic preferences as soon as we introduce limited liability.

Our findings of initially decreased risk taking are in line with responsibility alleviation, and we found that investors seek to act according to the perceived preferences of their clients. Our participants were aware of their relative risk preferences in that money managers with low risk aversion sought lower risks for others than for themselves and money managers with high risk aversion increased the risks taken for their clients. When the decision maker bears the same consequences as their clients (ALL), the clients' preferences seem to outweigh the money manager's own preferences. This situation changed drastically once we introduced limited 
liability in the form of convex incentives. Promising a five percent share of the possible returns on investment, with losses being incurred only by the clients, was sufficient to increase the investment levels by more than 77 percent. While the perception of what the clients would prefer did not change, money managers nonetheless follow their own egoistic preferences and invest much more. The emerging picture is that while decision makers initially try to accomplish what their clients want and overall take lower risks for others, the convex incentives reverse the decision. Apparently, social preferences are largely crowded out by egoistic monetary incentives. The fact that in one treatment the expected profit was even negative for the clients did not significantly change the money managers' behaviour. A clear sign that egoistic preferences are the main driver.

If one would want to draw conclusions for the financial markets, the recommendation is straightforward. A fee based on the success of the investment, without consequence in case of losses increases risk taking and potentially fosters bubble formation. Both a flat fee, as well as a bonus including negative consequences in case of losses for the client leads to investments that aim to follow the client's preferences. However, the results stem from a laboratory experiment and are not directly transferrable to the real world.

Our limited liability design is the first that applies convex incentives with consequences for other people's earnings in an experiment. This experimental design can be applied to answer more questions regarding 'privatizing profits and socializing losses' scenarios. Such a design could for example consider 'trust' in the fund industry when money managers compete which each other under convex incentives (Gennaioli et al. 2015 , Agranov et al., 2014) but can also be applied to asset market experiments to test whether such an environment indeed fosters asset market bubbles (Holmen et al. 2014 ).

\section{References}

Agranov, M., Bisin, A., Schotter, A., 2014. An experimental study of the impact of competition for other people's money: the portfolio manager market. Experimental Economics, 564-585.

Albrecht, K., Volz, K. G., Sutter, M., Laibson, D. I., Von Cramon, D. Y., 2011. What is for me is not for you: brain correlates of intertemporal choice for self and other. Social Cognitive and Affective Neuroscience 2, 218-225.

Allen, F., Gale, D., 2000. Bubbles and crises. The Economic Journal 110 (460), 236-255. 
Allen, F., Gorton, G., 1993. Churning bubbles. The Review of Economic Studies 60 (4), 813836.

Andersson, O., Holm, H. J., Tyran, J.-R., Wengström, E., 2016. Deciding for others reduces loss aversion. Management Science 62 (1), 29-36.

Bebchuk, L. A., Spamann, H., 2009. Regulating bankers' pay. Georgetown Law Journal 98, $247-287$.

Beisswanger, A. H., Stone, E. R., Hupp, J. M., Allgaier, L., 2003. Risk taking in relationships: Differences in deciding for oneself versus for a friend. Basic and Applied Social Psychology 25 (2), 121-135.

Berkowitz, L., Lutterman, K. G., 1968. The traditional socially responsible personality. Public Opinion Quarterly 32 (2), 169-185.

Bolton, G. E., Ockenfels, A., 2000. Erc: A theory of equity, reciprocity, and competition. American Economic Review 90 (1), 166-193.

Bolton, G. E., Ockenfels, A., 2006. Inequality aversion, efficiency, and maximin preferences in simple distribution experiments: comment. The American economic review 96 (5), 1906-1911.

Bolton, G. E., Ockenfels, A., 2010. Betrayal aversion: Evidence from brazil, china, oman, switzerland, turkey, and the united states: Comment. The American Economic Review $100(1), 628-633$.

Bolton, G. E., Ockenfels, A., Stauf, J., 2015. Social responsibility promotes conservative risk behavior. European Economic Review 74 (0), 109 - 127.

Chakravarty, S., Harrison, G. W., Haruvy, E. E., Rutström, E. E., 2011. Are you risk averse over other people's money? Southern Economic Journal 77 (4), 901-913.

Charness, G., 2000. Responsibility and effort in an experimental labor market. Journal of Economic Behavior \& Organization 42 (3), 375-384.

Charness, G., Gneezy, U., 2012. Strong evidence for gender differences in risk taking. Journal of Economic Behavior \& Organization 83 (1), 50-58.

Charness, G., Gneezy, U., Halladay, B., 2016. Experimental methods: Pay one or pay all. Journal of Economic Behavior \& Organization 131, 141-150. 
Charness, G., Gneezy, U., Imas, A., 2013. Experimental methods: Eliciting risk preferences. Journal of Economic Behavior \& Organization 87, 43-51.

Charness, G., Jackson, M. O., 2009. The role of responsibility in strategic risk-taking. Journal of Economic Behavior \& Organization 69 (3), 241-247.

Charness, G., Rabin, M., 2002. Understanding social preferences with simple tests. The Quarterly Journal of Economics 117 (3), 817-869.

Charness, G., Rabin, M., 2005. Expressed preferences and behavior in experimental games. Games and Economic Behavior 53 (2), 151-169.

Cheung, S. L., Coleman, A., 2014. Relative performance incentives and price bubbles in experimental asset markets. Southern Economic Journal 81 (2), 345-363.

Cvetkovich, G., 1972. Effects of sex on decision policies used for self and decision policies used for other persons. Psychonomic Science 26 (6), 319-320.

Dewatripont, M., Rochet, J.-C., Tirole, J., 2010. Balancing the banks: Global lessons from the financial crisis. Princeton University Press.

Dohmen, T., Falk, A., Huffman, D., Sunde, U., Schupp, J., Wagner, G. G., 2011. Individual risk attitudes: Measurement, determinants, and behavioral consequences. Journal of the European Economic Association 9 (3), 522-550.

Eckel, C. C., Grossman, P. J., 2008a. Forecasting risk attitudes: An experimental study using actual and forecast gamble choices. Journal of Economic Behavior \& Organization 68 (1), $1-17$.

Eckel, C. C., Grossman, P. J., 2008b. Men, women and risk aversion: Experimental evidence. Handbook of experimental economics results 1 (7), 1061-73.

Eriksen, K. W., Kvaløy, O., 2010. Myopic investment management. Review of Finance 14 (3), $521-542$.

Fehr, E., Schmidt, K. M., 1999. A theory of fairness, competition, and cooperation. The Quarterly Journal of Economics 114 (3), 817-868.

Fischbacher, U., 2007. z-tree: Zurich toolbox for ready-made economic experiments. Experimental Economics 10 (2), 171-178. 
Foerster, S., Linnainmaa, J. T., Melzer, B. T., Previtero, A., 2017. Retail financial advice: does one size fit all? The Journal of Finance 72 (4), 1441-1482.

Fox, C. R., Tversky, A., 1995. Ambiguity aversion and comparative ignorance. The Quarterly Journal of Economics 110 (3), 585-603.

French, K., Baily, M., Campbell, J., Cochrane, J., Diamond, D., Duffie, D., Kashyap, A., Mishkin, F., Rajan, R., Scharfstein, D., et al., 2010. The squam lake report: fixing the financial system. Journal of Applied Corporate Finance 22 (3), 8-21.

Fudenberg, D., Levine, D. K., 2012. Fairness, risk preferences and independence: Impossibility theorems. Journal of Economic Behavior \& Organization 81 (2), 606-612.

Füllbrunn, S. C., Luhan, W. J., 2017. Decision making for others: The case of loss aversion. Economics Letters 161, 154-156.

Garcia-Retamero, R., Galesic, M., 2012. Doc, what would you do if you were me? on selfother discrepancies in medical decision making. Journal of Experimental Psychology: Applied $18(1), 38$.

Gennaioli, N., Shleifer, A., Vishny, R., 2012. Neglected risks, financial innovation, and financial fragility. Journal of Financial Economics 104 (3), 452-468.

Gennaioli, N., Shleifer, A., Vishny, R., 2015. Money doctors. The Journal of Finance 70 (1), $91-114$.

Gneezy, U., Potters, J., 1997. An experiment on risk taking and evaluation periods. The Quarterly Journal of Economics 112 (2), 631-645.

Harbaugh, W. T., Krause, K., Vesterlund, L., 2010. The fourfold pattern of risk attitudes in choice and pricing tasks. The Economic Journal 120 (545), 595-611.

Harrison, G. W., 2006. Hypothetical bias over uncertain outcomes. In: List, J. A. (Ed.), Using epxperimental methods in environmental and resource economics. Northampton. MA: Elgar, pp. $41-69$.

Holmen, M., Kirchler, M., Kleinlercher, D., 2014. Do option-like incentives induce overvaluation? evidence from experimental asset markets. Journal of Economic Dynamics and Control 40, 179-194.

Holt, C. A., Laury, S. K., 2002. Risk aversion and incentive effects. American Economic Review $92(5), 1644-1655$. 
Holt, C. A., Laury, S. K., 2005. Risk aversion and incentive effects: New data without order effects. The American Economic Review 95 (3), 902-904.

Hsee, C. K., Weber, E. U., 1997. A fundamental prediction error: Self-others discrepancies in risk preference. Journal of Experimental Psychology: General 126 (1), 45.

Kahneman, D., Tversky, A., 1979. Prospect theory: An analysis of decision under risk. Econometrica: Journal of the Econometric Society, 263-291.

Kirchler, M., Lindner, F., Weitzel, U., 2019. Delegated decision making and social competition in the finance industry. Available at SSRN 3177459.

Kleinlercher, D., Huber, J., Kirchler, M., 2014. The impact of different incentive schemes on asset prices. European Economic Review 68, 137-150.

Pahlke, J., Strasser, S., Vieider, F. M., 2012. Risk-taking for others under accountability. Economics Letters 114 (1), 102-105.

Pahlke, J., Strasser, S., Vieider, F. M., 2015. Responsibility effects in decision making under risk. Journal of Risk and Uncertainty 51 (2), 125-146.

Pollmann, M. M., Potters, J., Trautmann, S. T., 2014. Risk taking by agents: The role of ex-ante and ex-post accountability. Economics Letters 123 (3), 387-390.

Polman, E., 2012. Self-other decision making and loss aversion. Organizational Behavior and Human Decision Processes 119 (2), 141-150.

Rajan, R. G., 2006. Has finance made the world riskier? European Financial Management $12(4), 499-533$.

Reynolds, D. B., Joseph, J., Sherwood, R., 2009. Risky shift versus cautious shift: determining differences in risk taking between private and public management decision-making. Journal of Business \& Economics Research 7 (1).

Ross, L., Greene, D., House, P., 1977. The "false consensus effect": An egocentric bias in social perception and attribution processes. Journal of Experimental Social Psychology 13 (3), 279301.

Stone, E. R., Allgaier, L., 2008. A social values analysis of self-other differences in decision making involving risk. Basic and Applied Social Psychology 30 (2), 114-129. 
Stoner, J. A. F., 1961. A comparison of individual and group decisions involving risk. Ph.D. thesis, Massachusetts Institute of Technology.

Sutter, M., 2009. Individual behavior and group membership: Comment. The American Economic Review 99 (5), 2247-2257.

Swalm, R. O., 1966. Utility theory-insights into risk taking. Harvard Business Review 44 (6), $123-136$.

Trautmann, S. T., Kuilen, G., 2015. Belief elicitation: A horse race among truth serums. The Economic Journal 125 (589), 2116-2135.

Trautmann, S. T., Van De Kuilen, G., 2015. Ambiguity attitudes. The Wiley Blackwell handbook of judgment and decision making 1, 89-116.

Trope, Y., Liberman, N., 2010. Construal-level theory of psychological distance. Psychological Review 117 (2), 440.

Ubel, P. A., Angott, A. M., Zikmund-Fisher, B. J., 2011. Physicians recommend different treatments for patients than they would choose for themselves. Archives of Internal Medicine $171(7), 630-634$.

Viscusi, W. K., Magat, W. A., Huber, J., 1987. An investigation of the rationality of consumer valuations of multiple health risks. The RAND Journal of Economics, 465-479.

von Gaudecker, H.-M., van Soest, A., Wengström, E., 2012. Experts in experiments. Journal of Risk and Uncertainty 45 (2), 159-190.

Wray, L. D., Stone, E. R., 2005. The role of self-esteem and anxiety in decision making for self versus others in relationships. Journal of Behavioral Decision Making 18 (2), 125-144. 


\section{Appendix}

\section{A Regressions}

In the tables A.5 and A.6, we regress the investment levels for the clients $\left(X_{O}\right.$ and $\left.X_{L}\right)$ and the shifts $\left(S_{O}\right.$ and $\left.S_{L}\right)$ in OTH and LIM respectively on different treatments (dummy for LIM (LIM), dummy for high payment in OTH (High Payment), dummy for high fee in LIM (High $\mathrm{Fee})$ ), on order (whether decision making for others (OTH or LIM) was first or last (Order $=1$ if last), and on subjects' background (general risk (Risk), female dummy (Female), age (Age), dummy for the field of study being economics (Econ), and social responsibility $(S R S)$ ).

General risk equals the self-reported risk preference in form of a likert scale question from one to ten with a higher number indicating a higher willingness to take risks(Dohmen et al. 2011). The social responsibility score was taken from Berkowitz and Lutterman (1968)).

Table A.5 considers three OLS regressions considering the 140 observations without limited liability (model 2) and the 105 observations with limited liability (model 3), and a model including both (model 1) clustered at session level. The first model neglects the additional treatments with higher payments in OTH (fixed payment was 31.50 euro instead of zero) or higher fees in LIM (fee was 50 percent instead of 5 percent). The results reflect our observations. Limited liability increases the shift significantly (observation 3. General risk decreases the shift significantly 1 in model 2. However, general risk plays no significant role in model 3 . The additional treatments High Payment and High Fee show no or a weak correlation with the shift, i.e. high payments for the money managers in OTH do not change risk taking for others but a higher fee in LIM tends to reduces risk taking for other. The social responsibility score has no influence on the shift. 
Table A.5: Investment shifts in OTH $\left(S_{O}\right)$ and $\operatorname{LIM}\left(S_{L}\right)$

\begin{tabular}{lccc}
\hline & All & No Limited & Limited Liability \\
Liability & & \\
\hline Order & $0.80^{* * *}$ & 0.41 & $\left(.18^{* * *}\right.$ \\
LIM & $(0.24)$ & $(0.24)$ & \\
General Risk & $2.92^{* * *}$ & & -0.11 \\
Social Responsibility Score & $(0.25)$ & $-0.34^{* * *}$ & $(0.22)$ \\
& $-0.36^{* * *}$ & $(0.11)$ & -0.27 \\
Female & $(0.100)$ & 0.025 & $(0.39)$ \\
Econ & 0.16 & $(0.33)$ & 0.044 \\
Age & $(0.26)$ & -0.10 & $(0.32)$ \\
High Payment & 0.099 & $(0.36)$ & 0.15 \\
High Fee & $(0.29)$ & -0.35 & $(0.46)$ \\
Constant & -0.31 & $(0.34)$ & -0.073 \\
& $(0.27)$ & $0.091^{*}$ & $(0.053)$ \\
Observations & 0.023 & $(0.046)$ & \\
Adjusted $R^{2}$ & $(0.043)$ & 0.044 & $-0.66^{*}$ \\
\hline
\end{tabular}

Notes. Variables explained above. Standard errors in parentheses. The asterisks refer to the p-value from a permutation test testing the $H_{0}$ that the shift equals zero $(*=\mathrm{p}<0.1, * *=\mathrm{p}<0.05, * * *=\mathrm{p}<0.01)$.

Table A.6 considers similar regressions as table A.6. However, we now consider investment levels instead of investment shifts and make use of truncated regressions censored at $X=0$ and $X=9$. Money managers invest significantly more for their clients when limited liable. Further on, order plays a role in the experiments with limited liability, i.e. subjects invest more when LIM is played last. The money makers willingness to take risk is also reflected in the decision for others, i.e. the higher the willingness to take risks, the higher the risk money managers take for others. Finally, females seem to take less risk for their clients when limited liable. 
Table A.6: Investment levels in OTH $\left(X_{O}\right)$ and LIM $\left(X_{L}\right)$

\begin{tabular}{lccc}
\hline & All & $\begin{array}{c}\text { No Limited } \\
\text { Liability }\end{array}$ & Limited Liability \\
\hline Order & $0.74^{* *}$ & 0.094 & $1.46^{* * *}$ \\
LIM & $(0.30)$ & $(0.25)$ & $(0.39)$ \\
General Risk & $3.52^{* * *}$ & & \\
Social Responsibility Score & $(0.31)$ & $0.28^{* *}$ & 0.25 \\
& 0.16 & $(0.12)$ & $(0.29)$ \\
Female & $(0.12)$ & 0.32 & 0.17 \\
& 0.24 & $(0.43)$ & $(0.26)$ \\
Econ & $(0.36)$ & -0.28 & $-1.74^{* *}$ \\
Age & -0.72 & $(0.45)$ & $(0.67)$ \\
High Payment & $(0.45)$ & $-0.81^{*}$ & 0.095 \\
High Fee & $-0.90^{* *}$ & $(0.43)$ & $(0.92)$ \\
Constant & $(0.39)$ & $0.057^{*}$ & $-0.14^{*}$ \\
& 0.0094 & $(0.033)$ & $(0.082)$ \\
Observations & $(0.046)$ & 0.22 & -0.68 \\
& & $(0.41)$ & $(0.74)$ \\
& & & $9.01^{* * *}$ \\
& & 0.49 & $(3.05)$ \\
\hline
\end{tabular}

Notes. Variables explained above. Standard errors in parentheses. The asterisks refer to the p-value from a permutation test testing the $H_{0}$ that the shift equals zero $(*=\mathrm{p}<0.1, * *=\mathrm{p}<0.05, * * *=\mathrm{p}<0.01)$.

\section{B Sessions with IND, ALL, and OTH}

\section{B.1 Order Effects}

To test whether an order effect has an impact on investment levels, we compare 70 observations in which subjects made investment decisions in the order OTH-IND-ALL and 70 observations in the order ALL-IND-OTH.

We make use of a permutation tests to evaluate the Null that investment levels and shifts do not differ comparing the two different orders. As table B.7 indicates, the order of the treatments has no effect on the main variables of interest. Further on, observation 1 also holds each of the two subsets. 
Table B.7: Order Differences

\begin{tabular}{cccc}
\hline & OTH-IND-ALL $(70)$ & ALL-IND-OTH $(70)$ & Difference (p-value) \\
\hline$X_{I}$ & $4.68(2.59)$ & $4.37(2.25)$ & $0.30(0.461)$ \\
$X_{A}$ & $3.85(1.95)$ & $4.00(1.88)$ & $-0.15(0.637)$ \\
$X_{O}$ & $3.91(1.85)$ & $3.84(2.54)$ & $0.06(0.864)$ \\
$S_{A}$ & $-0.83^{* * *}(1.61)$ & $-0.38^{* *}(1.51)$ & $-0.45(0.088)$ \\
$S_{O}$ & $-0.77^{* * *}(2.11)$ & $-0.53^{*}(2.67)$ & $-0.24(0.558)$ \\
\hline & Notes. The table reports averages in investments and shifts in the three treatments separated by order. The last \\
\multicolumn{2}{l}{ column shows the p-values from a permutation test comparing the two previous columns. The asterisks refer to the } \\
p-value from a permutation test testing the $H_{0}$ that differences equal zero $(*=\mathrm{p}<0.1, * *=\mathrm{p}<0.05, * * *=\mathrm{p}<0.01)$.
\end{tabular}

\section{B.2 Fixed Payment Effects}

To test whether the payment condition for the money manager in OTH has an impact on investment levels we compare 70 observations with a zero payment for the decision maker and 35 observations with a payment of 31.50 euro for the decision maker (both in the order OTHIND-ALL). We find no significant difference comparing the two different payment conditions; the investment level in OTH and the shift are almost equal in both conditions. Table B.8 shows and overview of the results.

Table B.8: Fixed Payment Differences

\begin{tabular}{cccc}
\hline & $\pi_{m}=0(70)$ & $\pi_{m}=31.5(35)$ & Difference (p-value) \\
\hline$X_{O}$ & $3.91(1.85)$ & $4.03(2.26)$ & $-0.12(0.701)$ \\
$S_{O}$ & $-0.77^{* * *}(2.11)$ & $-0.63(2.37)$ & $-0.14(0.769)$ \\
\hline
\end{tabular}

Notes. The table reports averages in investments and shifts in the three treatments separated by order. The last column shows the p-values from a permutation test comparing the two previous columns. The asterisks refer to the p-value from a permutation test testing the $H_{0}$ that differences equal zero $(*=\mathrm{p}<0.1, * *=\mathrm{p}<0.05, * * *=\mathrm{p}<0.01)$.

\section{B.3 Risk Categorization via IND}

In the main text, we consider general risk as out measure for subjects' risk attitudes. However, we can also use $X_{I}$ as a measure for risk attitudes (Charness et al. 2013). If we replicate table 1 by using the categories "below median $X_{I}$ " and "above median $X_{I}$ " we find similar results which support observation 2 . 
Table B.9: Average Investments in euro

\begin{tabular}{|c|c|c|c|}
\hline & \multirow[b]{2}{*}{$n=140$} & \multicolumn{2}{|c|}{ Investment in IND } \\
\hline & & $\begin{array}{l}\text { below median investment } \\
\qquad(n=53)\end{array}$ & $\begin{array}{l}\text { above median investment } \\
\qquad(n=64)\end{array}$ \\
\hline$X_{I}$ & $4.53(2.42)$ & $2.27(0.87)$ & $6.67(1.73)$ \\
\hline$X_{A}$ & $3.92(1.91)$ & $2.46(1.18)$ & $5.24(1.73)$ \\
\hline$X_{O}$ & $3.87(2.21)$ & $2.60(1.62)$ & $4.92(2.16)$ \\
\hline$S_{A}$ & $-0.60^{* * *}(1.57)$ & $0.20(0.83)$ & $-1.43(1.83)$ \\
\hline$S_{O}$ & $-0.65^{* * *}(2.39)$ & $0.34(1.62)$ & $-1.75(2.61)$ \\
\hline
\end{tabular}

\section{B.4 Instructions}

Find below the translated instructions for the order OTH-IND-ALL. They start with general instructions, followed by the three separate instructions for each treatment which were distributed only when the preceding treatment was concluded. The German instructions are available upon request.

\section{INSTRUCTIONS}

Welcome to the experiment. Please do not talk to any other participant from now on. We kindly ask you to use only those functions of the PC that are necessary for the conduct of the experiment. The purpose of this experiment is to study decision behavior. You can earn real money in this experiment. Your payment will be determined solely by your own decisions according to the rules on the following pages. The data from the experiment will be anonymized and cannot be related to the identities of the participants. Neither the other participants nor the experimenter will find out which choices you have made and how much you have earned during the experiment.

\section{SUB EXPERIMENTS}

You will participate in three independent sub experiments followed by a short questionnaire. For each sub experiment you receive a new set of instructions. Of the three sub experiments only one will be paid out at the end of the experiment. The payoff relevant experiment will be randomly determined by the roll of a die.

\section{EXPERIMENT 1}

[Treatment $O T H]$

Groups - At the begin of the experiments you will be randomly organized in groups of seven participants. Your group affiliation has no impact on your tasks or our payment.

Role - In this part participants are either active or passive members. In each group there is only one active member. This member decides for the other six members and, thereby, determines their payoff. The active group member will randomly be determined at the end of the experiment. First, all participants decide as the active member for all other group members. At the end of the experiment the real active member will be determined and his decision will be implemented.

Task - In the following your decision as an active member will be explained. The passive members receive 9 euro each. You now decide for each of the other members how much of their 9 euro to invest in a risky project. The investment is the same for each passive group member, i.e., when you invest a certain amount then you invest this amount for each passive group member. The remaining amount (9 euro - Investment) will be paid out to each passive member independent of the project's success. 
The project is either a success or a failure. In case of a success each passive member gets her invested amount back and in addition receives 2.5 times of the investment as a gain:

Payment in case of success $=9+2.5 \times$ Investment.

In case of a failure the investment is lost:

Payment in case of failure $=9$ - Investment.

Whether the project is successful will be determined by the throw of a six-sided die at the end of the experiment. In case of a five or six, the project is a success, in case of a one, two, three or four the project is a failure. The probability of success is therefore $33.33 \%$.

The active member receives no payoff in this sub experiment.

Procedure - Details on how to enter the investments - calculation of potential payments, fields of entry, etc - will be displayed on the upper part of your screen once the experiment has started.

\section{EXPERIMENT 2}

[Treatment IND]

In this experiment you decide only for yourself, independent of the other participants. You receive 9 euro and decide how much of their 9 euro to invest in a risky project. The remaining amount (9 euro - Investment) will be paid out independent of the project's success.

The project is either a success or a failure. In case of a success You will get your invested amount back and in addition receive 2.5 times of the investment as a gain:

Payment in case of success $=9+2.5 \times$ Investment.

In case of a failure the investment is lost:

Payment in case of failure $=9$-Investment.

Whether the project is successful will be determined by the throw of a six-sided die at the end of the experiment. In case of a five or six, the project is a success, in case of a one, two, three or four the project is a failure. The probability of success is therefore $33.33 \%$.

Procedure - Details on how to enter the investments - calculation of potential payments, fields of entry, etc - will be displayed on the upper part of your screen once the experiment has started.

\section{EXPERIMENT 3}

[Treatment $A L L]$

Groups - At the begin of the experiments you will be randomly organized in groups of seven participants. You will be regrouped, this means that the group members are not the same as in the first sub experiment. Your group affiliation has no impact on your tasks or your payment.

Role - In this part participants are either active or passive members. In each group there is only one active member. This member decides for himself and the other six members and, there by, determines the payoffs for the whole group. The active group member will randomly be determined at the end of the experiment.First, all participants decide as the active member for all group members. At the end of the experiment the real active member will be determined and his decision will be implemented.

Task - In the following your decision as an active member will be explained. Each group member (active and passive) members receives 9 euro each. You now decide for each member of the group, including yourself, how much of the 9 euro to invest in a risky project. The investment is the same for each passive group member, i.e., when you invest a certain amount then you invest this amount for yourself and for each passive group member. The remaining amount (9 euro - Investment) will be paid out to each group member independent of the project's success.

The project is either a success or a failure. In case of a success each group member gets her invested amount back and in addition receives 2.5 times of the investment as a gain:

Payment in case of success $=9+2.5 \times$ Investment.

In case of a failure the investment is lost:

Payment in case of failure $=9$-Investment.

Whether the project is successful will be determined by the throw of a six-sided die at the end of the experiment. In case of a five or six, the project is a success, in case of a one, two, three or four the project is a failure. The probability of success is therefore $33.33 \%$. 
Procedure - Details on how to enter the investments - calculation of potential payments, fields of entry, etc - will be displayed on the upper part of your screen once the experiment has started.

\section{END OF EXPERIMENT}

At first we will determine, by the roll of a die, which experiment will determine your payoff. Thereafter, a separate dice roll for each group will determine whether the project was successful or not. After you answered a short questionnaire your payment will be shown at your screen. Please enter the amount on your receipt. You will be called individually to the payoff desk. Please bring the small number plate and the signed receipt with you. The payment will be in cash, private and anonymous.

\section{B.5 Decision Screens}

Figures B.9 to B.9 provide screenshots of the investment decisions in each treatment. Subjects were able to enter arbitrary investment levels in the field "EINSATZ in euro" (Investment in euro). A click on the gray button (Generate Payoffs) added a new line to a table. The table listed the chosen investment and the potential payoffs for the passive and the active members together depending on the treatments together with the respective probabilities. The ultimate investment was chosen by marking one line in the list and by clicking the red button (CONFIRM YOUR DEFINITIVE INVESTMENT). Then a pop-up asked whether the decision is ultimate or whether the subject wants to revise it. In this example, the subject first entered an investment amount of 2.86 euro, then 1.75 euro, and then 8.62 euro. The amount 5.67 euro was not generated yet. However, the investment 1.75 euro was chosen and the red button opened the dialog for a final confirmation of the choice. The z-Tree code is available upon request. 
Figure B.9: Screenshot of Investment Decision: IND

\section{DURCHFÜHRUNG}

Geben Sie in das Feld EINSATZ einen beliebigen Betrag bis maximal 9.00 Euro ein und klicken Sie auf die Schaltfläche AUSZAHLUNGEN GENERIEREN. Sie können bis zu zwei Nachkommastellen (Cent) eingeben.

Für jeden Einsatz wird die Auszahlung bei Erfolg und bei Misserfolg des Projektes in der Tabelle angezeigt

Nachdem Sie sich für einen Einsatz entschieden haben, markieren Sie die entsprechende Zeile aus der Tabelle indem Sie auf die Zeile klicken (diese wird blau unterlegt)

Durch betätigen der Schaltfläche BESTÄTIGEN SIE ENTGÜLTIG DEN EINSATZ wird der marktierte Einsatz in das Projekt investiert

Überlegen Sie Ihre Möglichkeiten sorgfältig und treffen Sie dann Ihre Wahl.

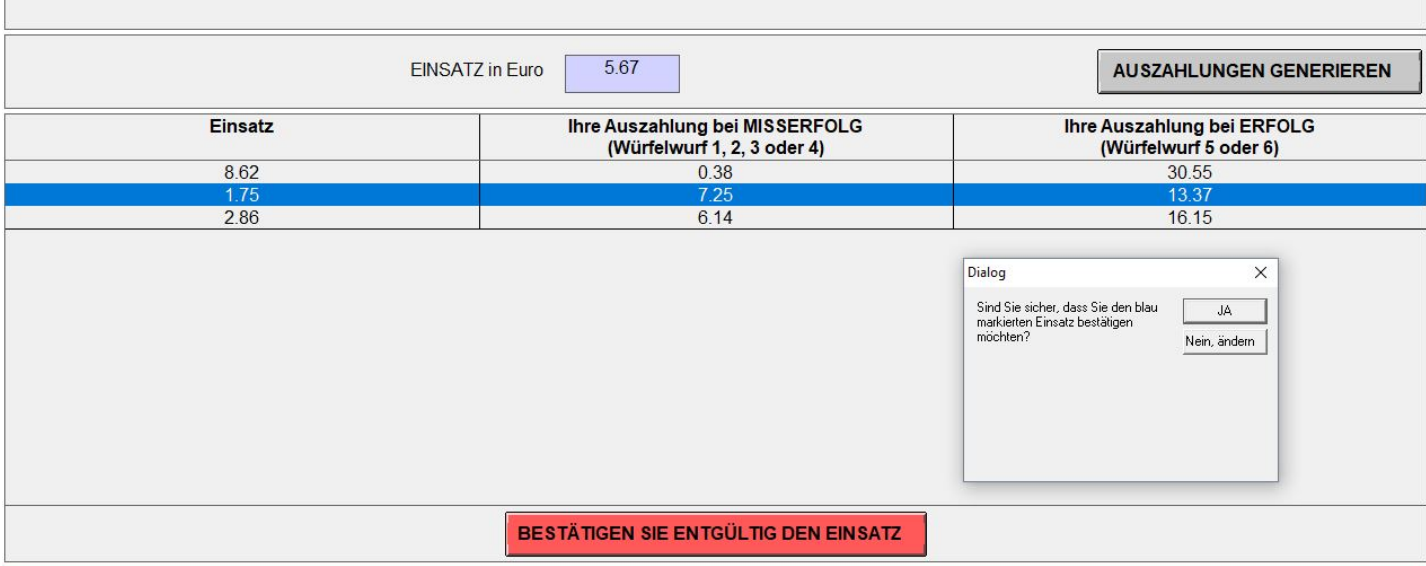

Bedenken Sie: Die Auszahlung aus dieser Aufgabe ist unter Umständen...

die einzige Auszahlung für Sie. 
Figure B.9: Screenshot of Investment Decision: ALL

\section{DURCHFÜHRUNG}

Geben Sie in das Feld EINSATZ einen beliebigen Betrag bis maximal 9.00 Euro ein und klicken Sie auf die Schaltfläche AUSZAHLUNGEN GENERIEREN. Sie können bis zu zwei Nachkommastellen (Cent) eingeben.

Für jeden Einsatz wird die Auszahlung bei Erfolg und bei Misserfolg des Projektes in der Tabelle angezeigt.

Nachdem Sie sich für einen Einsatz entschieden haben, markieren Sie die entsprechende Zeile aus der Tabelle indem Sie auf die Zeile klicken (diese wird blau unterlegt)

Durch betätigen der Schaltfläche BESTÄTIGEN SIE ENTGÜLTIG DEN EINSATZ wird der marktierte Einsatz in das Projekt investiert

Überlegen Sie Ihre Möglichkeiten sorgfaltig und treffen Sie dann Ihre Wahl.

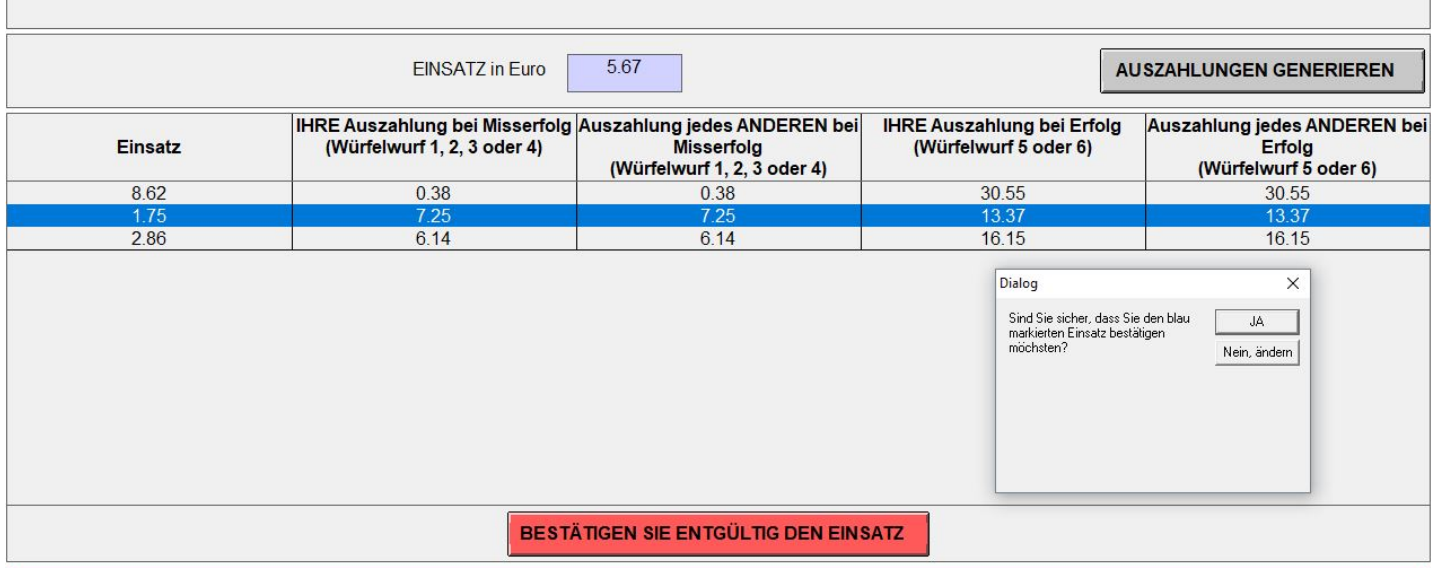

Bedenken Sie: Die Auszahlung aus dieser Aufgabe ist unter Umständen

die einzige Auszahlung für Sie.

die einzige Auszahlung für jedes der anderen 6 Mitglieder Ihrer Gruppe. 
Figure B.9: Screenshot of Investment Decision: OTH

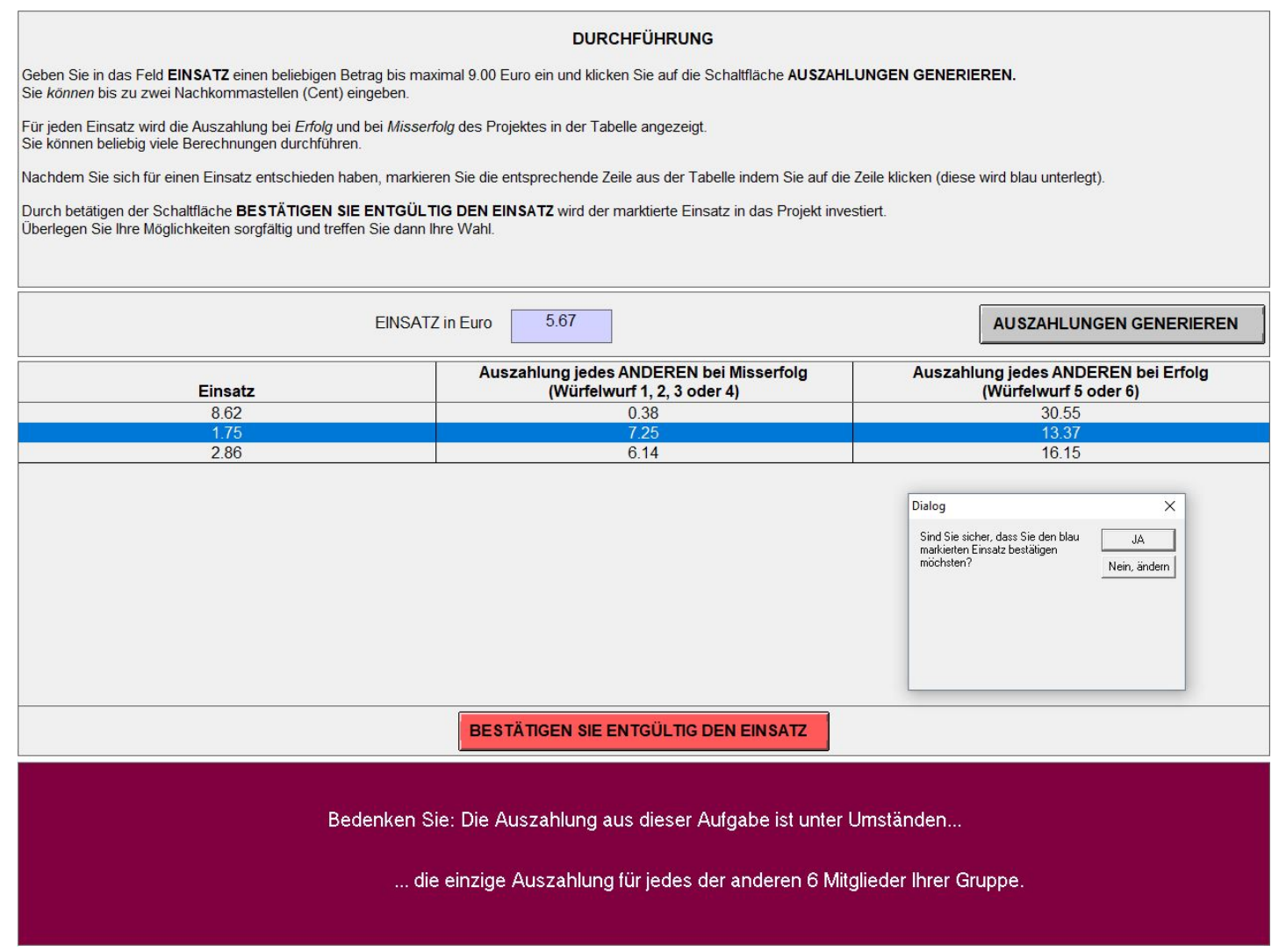

\section{Sessions with IND, ALL, and LIM}

\section{C.1 Order Effects}

To test whether an order effect has an impact on investment levels in LIM, we compare 49 observations in which subjects made investment decisions in the order LIM-IND-ALL and 56 observations in the order ALL-IND-LIM.

We make use of a permutation tests to evaluate the Null that investment levels and shifts do not differ comparing the two different orders. As table B.7 indicates, the order of the treatments has an effect on the main variables of interest. However, observation 1 also holds for the two subsets. 
Table C.10: Order Differences

\begin{tabular}{lccc}
\hline & LIM-IND-ALL (49) & ALL-IND-LIM (56) & Difference (p-value) \\
\hline$X_{I}$ & $4.77(1.85)$ & $4.34(2.19)$ & $0.34(0.284)$ \\
$X_{L}$ & $6.30(2.12)$ & $7.33(2.06)$ & $-1.03(0.013)$ \\
\hline$S_{L}$ & $1.52^{* * *}(2.49)$ & $2.98^{* * *}(2.67)$ & $-1.46(0.005)$ \\
\hline
\end{tabular}

Notes. The table reports averages in investments and shifts in LIM separated by order. The last column shows the p-values from a permutation test comparing the two previous columns. The asterisks refer to the p-value from a permutation test testing the $H_{0}$ that differences equal zero $(*=\mathrm{p}<0.1, * *=\mathrm{p}<0.05, * * *=\mathrm{p}<0.01)$.

\section{C.2 Instructions}

The instructions for LIM simply replace the instructions for OTH (Section B.4). Instructions for LIM50 just replaced the 5 percent by 50 percent.

\section{EXPERIMENT 1}

Groups - At the begin of the experiments you will be randomly organized in groups of seven participants. Your group affiliation has no impact on your tasks or our payment.

Role - In this part participants are either active or passive members. In each group there is only one active member. This member decides for the other six members and, thereby, determines their payoff. The active group member will randomly be determined at the end of the experiment. First, all participants decide as the active member for all other group members. At the end of the experiment the real active member will be determined and his decision will be implemented.

Task - In the following your decision as an active member will be explained. The passive members receive 9 euro each. You now decide for each of the other members how much of their 9 euro to invest in a risky project. The investment is the same for each passive group member, i.e., when you invest a certain amount then you invest this amount for each passive group member. The remaining amount (9 euro - Investment) will be paid out to each passive member independent of the project's success.

The project is either a success or a failure. In case of a success each passive member gets her invested amount back and in addition receives 2.5 times of the investment as a gain. The active member receives $5 \%$ from the gain of each passive member:

Payment in case of success

$$
\begin{aligned}
\text { Profit } & =2.5 \times \text { Investment } \\
\text { passive member } & =9+95 \% \times \text { Profit } \\
\text { active member } & =6 \times 5 \% \times \text { Profit }
\end{aligned}
$$

In case of a failure the investment is lost and the active member receives no payment

Payment in case of failure

$$
\begin{aligned}
\text { passive member } & =9-\text { Investment } \\
\text { active member } & =0
\end{aligned}
$$

Whether the project is successful will be determined by the throw of a six-sided die at the end of the experiment. In case of a five or six, the project is a success, in case of a one, two, three or four the project is a failure. The probability of success is therefore $33.33 \%$.

Procedure - Details on how to enter the investments - calculation of potential payments, fields of entry, etc - will be displayed on the upper part of your screen once the experiment has started. 


\section{C.3 Decision Screen}

Figures C.10 provides a screenshots of the investment decisions for treatment LIM similar to section B.5.

Figure C.10: Screenshot of Investment Decision: LIM

\section{DURCHFÜHRUNG}

Geben Sie in das Feld EINSATZ einen beliebigen Betrag bis maximal 9.00 Euro ein und klicken Sie auf die Schaltfläche AUSZAHLUNGEN GENERIEREN. Sie können bis zu zwei Nachkommastellen (Cent) eingeben.

Für jeden Einsatz wird die Auszahlung bei Erfolg und bei Misserfolg des Projektes in der Tabelle angezeigt. Sie können beliebig viele Berechnungen durchführen.

Nachdem Sie sich für einen Einsatz entschieden haben, markieren Sie die entsprechende Zeile aus der Tabelle indem Sie auf die Zeile klicken (diese wird blau unterlegt).

Durch betätigen der Schaltfläche BESTÄTIGEN SIE ENTGÜLTIG DEN EINSATZ wird der marktierte Einsatz in das Projekt investiert Überlegen Sie Ihre Möglichkeiten sorgfältig und treffen Sie dann Ihre Wahl.

\begin{tabular}{|l|l|l|}
\hline EINSATZ in Euro & 5.67 & AUSZAHLUNGEN GENERIEREN \\
\hline
\end{tabular}

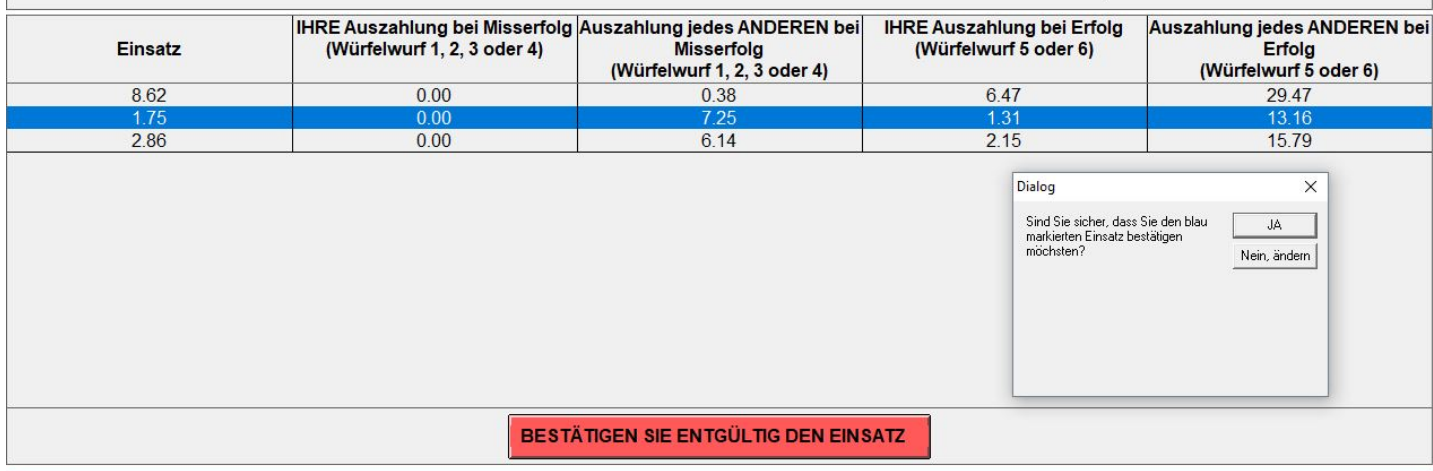

Bedenken Sie: Die Auszahlung aus dieser Aufgabe ist unter Umständen 


\section{Gender Effects}

We added this section for those researchers who are interested in gender effects in risk taking. Charness and Gneezy (2012) provide evidence for a gender effect in the Gneezy and Potters (1997) environment with varying payments and probabilities. To test whether a gender effect, or rather a sex effect, has an impact on investment levels, we compare the observations in which females made investment decisions to the observations in which males made investment decisions. As table D.11 indicates, males invest significantly more than females in IND, ALL, and LIM, i.e. in all treatments in which the money managers faces true outcome consequences. Investments in $\mathrm{OTH}$, however, are not different. The general patterns from observation 1 and 3 and holds for both sex though.

Table D.11: Gender differences

\begin{tabular}{lccc}
\hline & Males & Females & Difference $(\mathrm{p}$-value $)$ \\
\hline$X_{I}(162 / 132)$ & $4.99(2.41)$ & $3.91(1.82)$ & $1.08(<0.001)$ \\
$X_{A}(162 / 132)$ & $4.59(2.21)$ & $3.72(1.54)$ & $0.87(<0.001)$ \\
$X_{O}(75 / 65)$ & $4.14(2.37)$ & $3.56(1.99)$ & $0.58(0.119)$ \\
$X_{L}(59 / 46)$ & $7.20(2.12)$ & $6.39(2.11)$ & $0.81(0.055)$ \\
$S_{A}(162 / 132)$ & $-0.40^{* * *}(1.39)$ & $-0.19(1.38)$ & $-0.21(0.193)$ \\
$S_{O}(59 / 46)$ & $-0.69^{* *}(2.62)$ & $-0.61^{* *}(2.13)$ & $-0.08(0.842)$ \\
$S_{L}(75 / 65)$ & $1.84^{* * *}(2.56)$ & $2.89^{* * *}(2.69)$ & $-1.05(0.45)$ \\
\hline
\end{tabular}

Notes. The table reports averages in investments and shifts separated by sex. The numbers in column one report the number of observations for males and females (males/females). The last column shows the p-values from a permutation test comparing the two previous columns. The asterisks refer to the p-value from a permutation test testing the $H_{0}$ that differences equal zero $(*=\mathrm{p}<0.1, * *=\mathrm{p}<0.05, * * *=\mathrm{p}<0.01)$.

In a debriefing questionnaire, we ask several questions on risk aversion in line with Dohmen et al. (2011). Using a Mann-Whitney U test, we find significant gender differences in questions about risk taking in general $(p=0.004)$, driving a car $(p=0.019)$, and making financial decisions $(p=0.002)$. We find no effect in questions on risk taking in sports and leisure $(p=0.074)$. in career $(p=0.319)$, health $(p=0.937)$, trust in strangers $(p=0.567)$, or in a hypothetical investment decision $(p=0.132)$. 